\title{
Viral ecology of organic and inorganic particles in aquatic systems: avenues for further research
}

\author{
M. G. Weinbauer ${ }^{1,2, *}$, Y. Bettarel ${ }^{3}$, R. Cattaneo $^{1}$, B. Luef $^{4}$, C. Maier ${ }^{1}$, C. Motegi $^{1}$, \\ P. Peduzzi ${ }^{5}$, X. Mari ${ }^{6}$
}
${ }^{1}$ Microbial Ecology \& Biogeochemistry Group and Université Pierre et Marie Curie-Paris6, Laboratoire d'Océanographie de Villefranche, 06234 Villefranche-sur-Mer Cedex, France
${ }^{2}$ Centre National de la Recherche Scientifique (CNRS), Laboratoire d'Océanographie de Villefranche, 06234 Villefranche-sur-Mer, France

${ }^{3}$ Institut de Recherche pour le Développement, UMR 5119 ECOLAG, Université Montpellier II, 34095 Montpellier Cedex 5, France ${ }^{4}$ Life Sciences Division, Lawrence Berkeley National Laboratory, Berkeley, California 94720, USA

${ }^{5}$ Departement of Freshwater Ecology, Faculty of Life Sciences, University of Vienna, Vienna, Austria ${ }^{6}$ IRD, UMR 5119 ECOLAG, Noumea Center, BP A5, NC-98848 Noumea, New Caledonia

\begin{abstract}
Viral abundance and processes in the water column and sediments are well studied for some systems; however, we know relatively little about virus-host interactions on particles and how particles influence these interactions. Here we review virus-prokaryote interactions on inorganic and organic particles in the water column. Profiting from recent methodological progress, we show that confocal laser scanning microscopy in combination with lectin and nucleic acid staining is one of the most powerful methods to visualize the distribution of viruses and their hosts on particles such as organic aggregates. Viral abundance on suspended matter ranges from $10^{5}$ to $10^{11} \mathrm{ml}^{-1}$. The main factors controlling viral abundance are the quality, size and age of aggregates and the exposure time of viruses to aggregates. Other factors such as water residence time likely act indirectly. Overall, aggregates appear to play a role of viral scavengers or reservoirs rather than viral factories. Adsorption of viruses to organic aggregates or inorganic particles can stimulate growth of the free-living prokaryotic community, e.g. by reducing viral lysis. Such mechanisms can affect microbial diversity, food web structure and biogeochemical cycles. Viral lysis of bacterio- and phytoplankton influences the formation and fate of aggregates and can, for example, result in a higher stability of algal flocs. Thus, viruses also influence carbon export; however, it is still not clear whether they short-circuit or prime the biological pump. Throughout this review, emphasis has been placed on defining general problems and knowledge gaps in virus-particle interactions and on providing avenues for further research, particularly those linked to global change.
\end{abstract}

KEY WORDS: Viruses · Bacteria $\cdot$ Prokaryotes $\cdot$ Aggregates

Resale or republication not permitted without written consent of the publisher

\section{INTRODUCTION}

Viruses, the microbial food web and sinking fluxes

The current concept of the microbial food web was developed in several paradigm shifts. One was that the classical grazing food chain consisting of phytoplank- ton, grazers and carnivores was extended by the microbial food web. In this microbial loop (Pomeroy 1974, Azam et al. 1983), dissolved organic matter (DOM), which would otherwise be lost from the food web, is utilized, i.e. oxidized or converted into biomass by prokaryotes (here used for Bacteria plus Archaea). This has important consequences for biogeochemical 
cycles, since the amount of carbon stored in the dissolved organic carbon (DOC) pool is approximately as high as carbon stored in atmospheric $\mathrm{CO}_{2}$ (Hedges 2002). In addition, prokaryotic carbon serves as a food source for small protists, mainly flagellates and ciliates, and thus transfers some carbon back to higher trophic levels. About 2 decades ago, viruses were identified as the most abundant signs of life (Bergh et al. 1989) and as major sources of mortality for phyto- and bacterioplankton (Proctor \& Fuhrman 1990, Suttle et al. 1990). In addition, viral lysis products from cells can be taken up by (infected and non-infected) prokaryotes. This viral loop or short-circuit (Bratbak et al. 1992), which produces DOM and small detrital matter, is called the viral shunt (Wilhelm \& Suttle 1999). The main consequences of the viral shunt seem to be: (1) conversion of prokaryotic biomass into DOM and small detritus and diversion from grazing (Fuhrman 1999), (2) stimulation of DOM use, thus catalyzing nutrient cycling (Suttle 2005) and (3) overall lubrication of the microbial food web (Allen \& Wilson 2008).

In addition to the grazing food chain, the microbial loop and the viral shunt, the vertical and horizontal transport of particles (marine, lake and riverine snow) influences system productivity and organic carbon flux. Downward export of organic aggregates is a means to remove organic carbon from the euphotic layer by transporting it into the interior of the ocean (biological pump) (Azam \& Long 2001). Similar vertical processes are operational in lakes. Suspended matter (containing organic and inorganic particles) is a means of horizontal carbon transport in rivers, estuaries and tidal flats. Another important realization was that oceans (and probably also inland waters) are more heterogeneous, on very small spatial scales, than previously thought (Azam 1998, Long \& Azam 2001, Azam \& Malfatti 2007); this idea is also linked to aggregates in the sense that microbial abundance and activity is high on aggregates (e.g. Simon et al. 2002). Such a spatial heterogeneity creates multiple gradients and ecological niches which probably contribute to the sustenance of species diversity. Thus, currently, organic aggregates are typically considered as hot spots of biogeochemical transformation and prokaryotic activity.

\section{The organic matter continuum and inorganic particles}

Organic matter in pelagic systems is separated into DOM and particulate organic matter (POM) (Nagata 2008). This separation is based on the operational criterion of size and is typically done by filtration through GF/F (nominal pore-size $0.7 \mu \mathrm{m}$ ) or $0.2 \mu \mathrm{m}$-filters. The rationale behind this is to separate cells from DOM. Not surprisingly, such arbitrary and operational definitions are flawed. For example, some cells even pass through $0.2 \mu \mathrm{m}$-filters. Most viruses are part of the DOM pool due to their small size; however, some viruses are larger than small cells and thus belong to the POM pool. In addition, a significant fraction of small viruses can be retained by using $0.2 \mu \mathrm{m}$-filters.

Non-living organic matter in pelagic systems occurs in a size continuum from dissolved molecules to aquatic snow (Nagata \& Kirchman 1997). Several types of non-living organic particles have been described for aquatic environments (Nagata 2008): small colloids (Wells \& Goldberg 1991), submicrometer particles (Koike et al. 1990), Coomassie Brilliant Blue-stained particles (CSP) (Long \& Azam 1996), DAPI positive yellow particles (DYP) (Mostajir et al. 1995), transparent exopolymeric particles (TEP) stained with Alcian Blue (Alldredge et al. 1993) and mm-sized or larger particles often referred to as marine, lake or riverine snow (Silver et al. 1978, Grossart \& Simon 1993, Neu 2000). The recent discovery of a new class of organic particles, filter fluorescing particles (FFP) (Samo et al. 2008), suggests that future research will enrich the already complex world of particles. Seawater is currently considered as a diluted gel with gels or gel-like structures of different sizes that can be formed in minutes to hours from DOM or polymer chains released by phyto- or bacterioplankton, hence bridging the DOM-POM continuum (Chin et al. 1998, Verdugo et al. 2004).

Other sources of POM are senescent phytoplankton or larvacean houses. Prokaryotes attached to aggregates typically produce more extracellular enzymes than their free-living counterparts (Karner \& Herndl 1992, Smith et al. 1992), and this results in the disintegration and dissolution of aggregates. However, prokaryotes can also be involved in the formation of organic aggregates (Biddanda 1985). Overall, prokaryotes play a pivotal role in the formation, transformation and degradation of aquatic aggregates and thus aggregate-mediated carbon flow (Simon et al. 2002).

Inorganic particles in the water column have recently received more attention (Nagata 2008). They can originate from sediment resuspension or river runoff, but can also have biological origins such as the silica frustules of diatoms or the calcium carbonate shells of coccolithophorids. Inorganic particles can take a significant part in the composition of aggregates. Other types of particles, which have not been sufficiently considered in aquatic microbial ecology, are aerosols and larger atmospheric particles, such as dust and black carbon, which can be introduced into the marine system via deposition. 


\section{Aim of review}

A large amount of data is available on the interaction of specific viruses (mainly those infecting humans and the prokaryotes, cultivated plants and domesticated animals) with inorganic surfaces (Farrah 1987, Moebus 1987). Many of these studies have tested materials for viral adsorption and inactivation in the water column. Here we review the knowledge on interactions of viral communities with organic and inorganic particles; studies from isolates are used when appropriate. In addition, we discuss knowledge gaps, provide examples for potential future research topics and present scenarios on how global change could impact such interactions.

\section{QUANTIFICATION OF VIRAL PARAMETERS ON PARTICLES: METHODS AND RESTRICTIONS}

Transmission electron microscopy (TEM) has been used to quantify viruses in the slime of diatoms (Bratbak et al. 1990) and on marine snow particles (Peduzzi \& Weinbauer 1993). Also, viruses have been directly observed on riverine aggregates using nucleic acid stains such as SYBR Green, SYBR Gold or DAPI and epifluorescence microscopy (EM) (Lisle \& Priscu 2004, Luef et al. 2007, Peduzzi \& Luef 2008) and confocal laser scanning microscopy (CLSM) (Luef et al. 2009a,b). This approach can be combined with probes such as

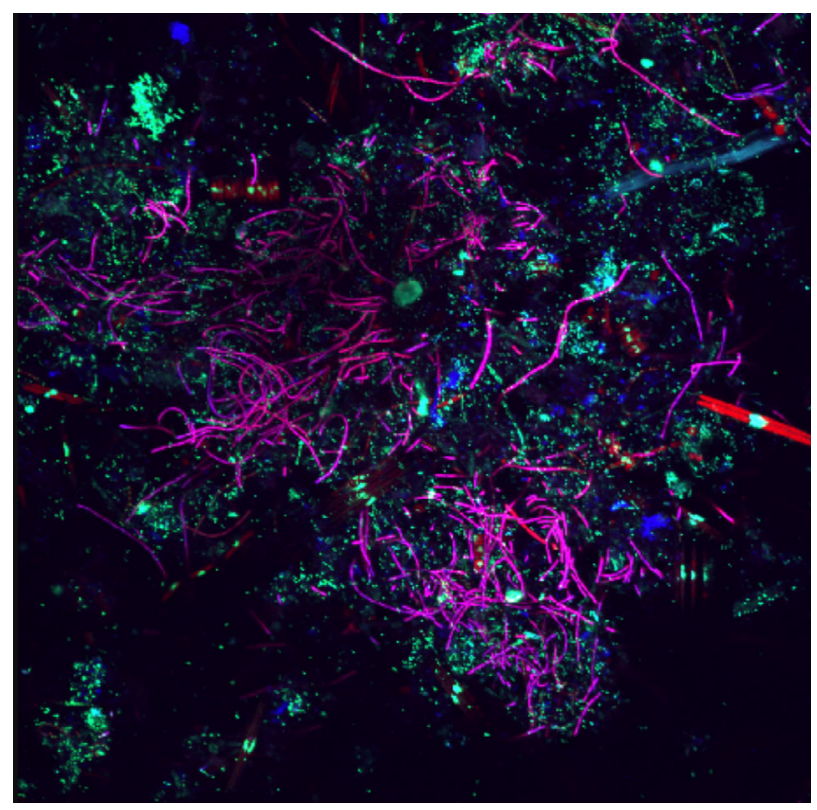

Fig. 1. Example of a large aggregate from a backwater system. Green: nucleic acids; blue: exopolymeric substances; red: autofluorescence of chlorophyll $a_{i}$ pink: exopolymeric substances and phycoerythrin (filamentous cyanobacteria); yellow-green: bacteria and viruses in or in contact with lectinspecific exopolymeric substances. lectins (Luef et al. 2009). The benefit of lectins is that they specifically bind to target molecules. An example of a large and complex river aggregate is shown in Fig. 1. Simpler marine and lake snow aggregates are shown in Figs. 2 \& 3. By selecting target molecules, one can also visualize specific compounds. The lectins for

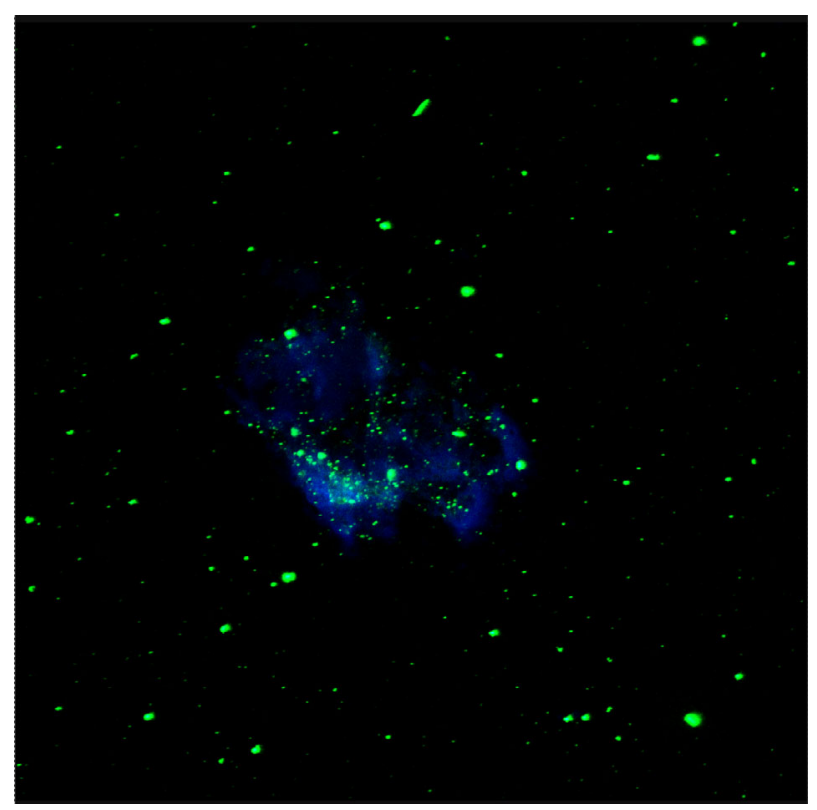

Fig. 2. Example of a marine snow aggregate. Green: nucleic acids; blue: exopolymeric substances

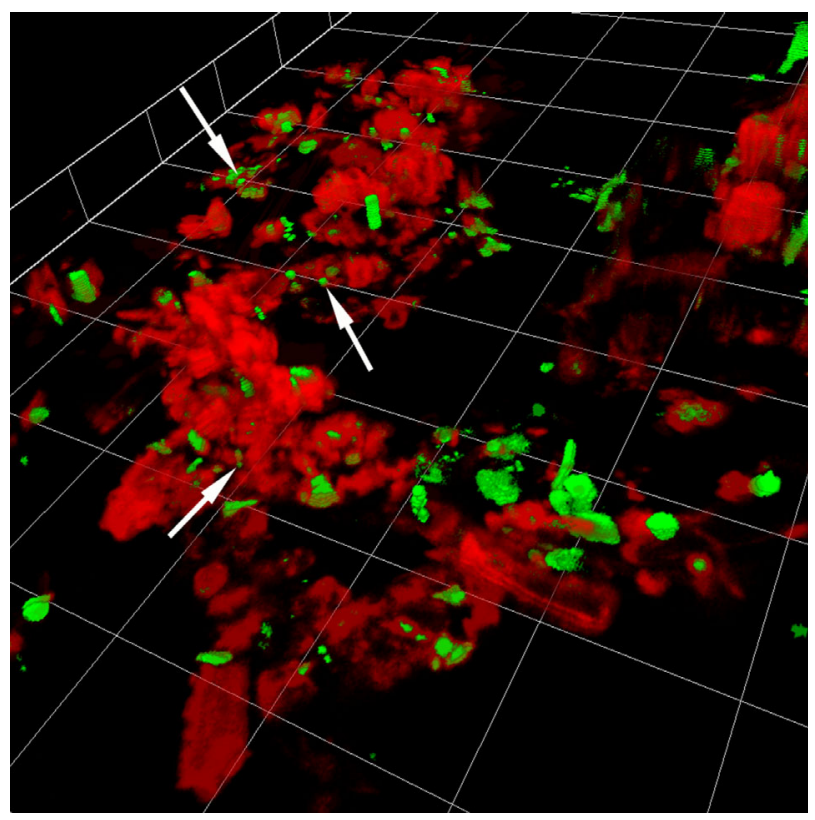

Fig. 3. 3D volume reconstructions from a river aggregate. Arrows point to viruses. Green: nucleic acid; red: glycoconjugates. Calibration grid $=5 \mu \mathrm{m}$. White arrows point to viruses. Note that a video for this type of analysis is available at: www.int-res.com/articles/suppl/a057p321_app/ 
$\mathrm{N}$-acetyl-beta-D-glucosaminyl residues and $\mathrm{N}$-acetylbeta-D-glucosamine oligomers have been used to detect exopolymeric substances such as prokaryotic capsules and cell walls. Using CLSM, aggregates are optically sectioned and investigated and then reconstructed from the optical sections. Examples of reconstructed organic aggregates are shown in Figs. 1-3. The laser light of CLSM cannot fully penetrate all aggregate material, e.g. in the case of riverine aggregates, this is due to scattering properties. However, studies of viruses (and prokaryotes) deeper in the aggregates can be done by cryosectioning of aggregates (Luef et al. 2009a,b). Aggregates are first physically sectioned and then single sections are inspected optically using CLSM. An example of a CLSM picture of a cryosection from a river aggregate is shown in Fig. 4. For particles such as black carbon or dust (see 'Other particles') the light reflection mode can be used to visualize the particle and the epifluorescence mode to detect viruses (and prokaryotes) (Figs. 5 \& 6).

A method was developed to estimate viral abundance on TEP by first measuring total viral abundance, then attaching paramagnetic beads to TEP and removing TEP magnetically and measuring viral abundance again; the difference is the number of TEP-associated viruses (Mari et al. 2007a). Comparisons between predicted versus measured TEP-associated viral abundance suggest an underestimation at high TEP density. This could be due to disruption of large TEP and organic aggregates during preparation for flow cytom-

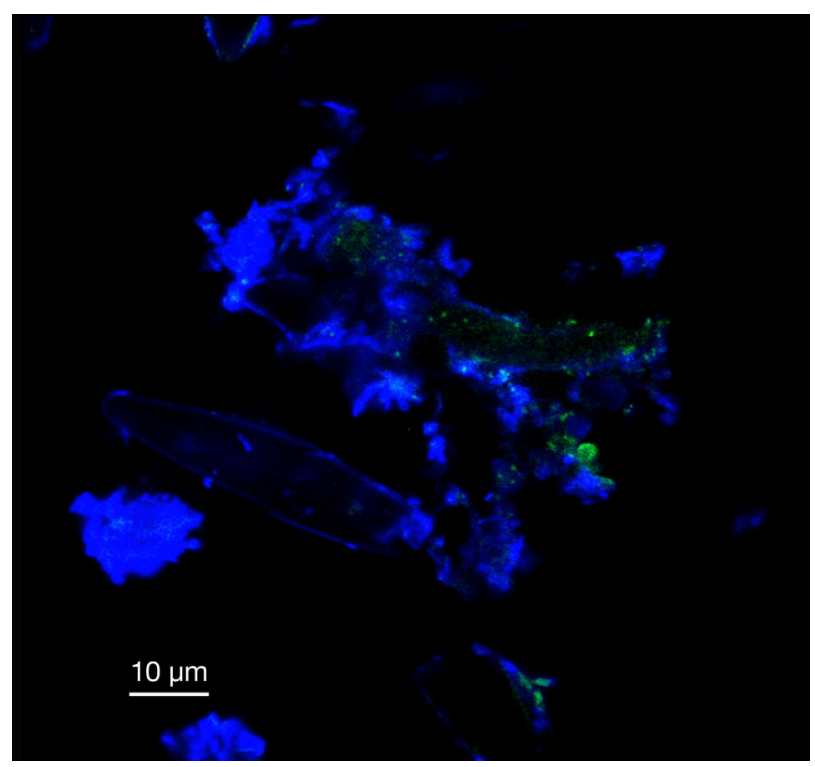

Fig. 4. Cryosection of a river aggregate. Single scan of a cryosection showing the distribution of viruses, bacteria and glycoconjugates inside an aggregate. Green: nucleic acids; blue: glycoconjugates etry $(\mathrm{FCM})$ and counting. Counts of viruses were also obtained after disruption of aggregates by pyrophosphate and sonication (Bongiorni et al. 2007). Recently, a method originally developed to disrupt organic aggregates for counting prokaryotes (Lunau et al. 2005) was applied to release phages from beads (Riemann \& Grossart 2008). This method dissolves aggregates using methanol and sonication, liberates viruses (and prokaryotes) and allows for quantification using EM. This has been tested for TEP, which were first associated with paramagnetic beads and then concentrated onto small magnets and kept hanging in seawater for several days. Fig. 7 shows that the methanol treatment and sonication disrupted these dense aggregates sufficiently to allow for counting of viruses. This method also works for other organic matrices such as coral mucus (R. Cattaneo et al. unpubl. data).

Methods for counting viruses directly on aggregates are still in their infancy, and so far no method allows automatic enumeration of attached viruses. CLSM can be used to enumerate viruses, but counting has still to be done manually (Luef et al. 2009). Similar observations were made for viruses on black carbon aggregates (R. Cattaneo et al. unpubl. data). Nevertheless, it is likely (Luef et al. 2009) that methodological progress will solve this problem and allow for automated counting. TEM could overestimate viral abundance, since aggregates can shrink during embedding. This problem could potentially be overcome by embedding in resins such as Nanoplast (Leppard et al. 1996). Since viruses can decay significantly within hours when fixed samples are not shock-frozen and stored at $-80^{\circ} \mathrm{C}$ (Brussaard 2004b, Wen et al. 2004), this could also result in underestimations of viral counts on aggregates by TEM. Unfortunately, methanol (used to disrupt organic aggregates and release attached-viruses) interferes with SYBR Green staining in cytograms and thus the benefits of FCM of a rapid sample throughput and determination of different populations cannot be used currently for the above-described methanol disruption approach. TEM and CLSM are time-consuming methods, but allow an assessment of the 3-dimensional distribution of viruses within the organic matrix of aggregates.

The only method applied so far for estimating viral infection of aggregate-associated cells is TEM (Proctor \& Fuhrman 1991). Thus we tested a modification of the virus-reduction approach (Wilhelm et al. 2002, Weinbauer et al. 2009c) to assess viral production in a TEP concentrate made from water collected in Noumea lagoon, SW New Caledonia. Aggregates were disrupted in $1.5 \mathrm{ml}$ virus-free seawater and sonicated for 5 min to disrupt aggregate for counting of viruses. The time-course change of viral abundance was assessed and subsamples were withdrawn in 2 to $4 \mathrm{~h}$ intervals 


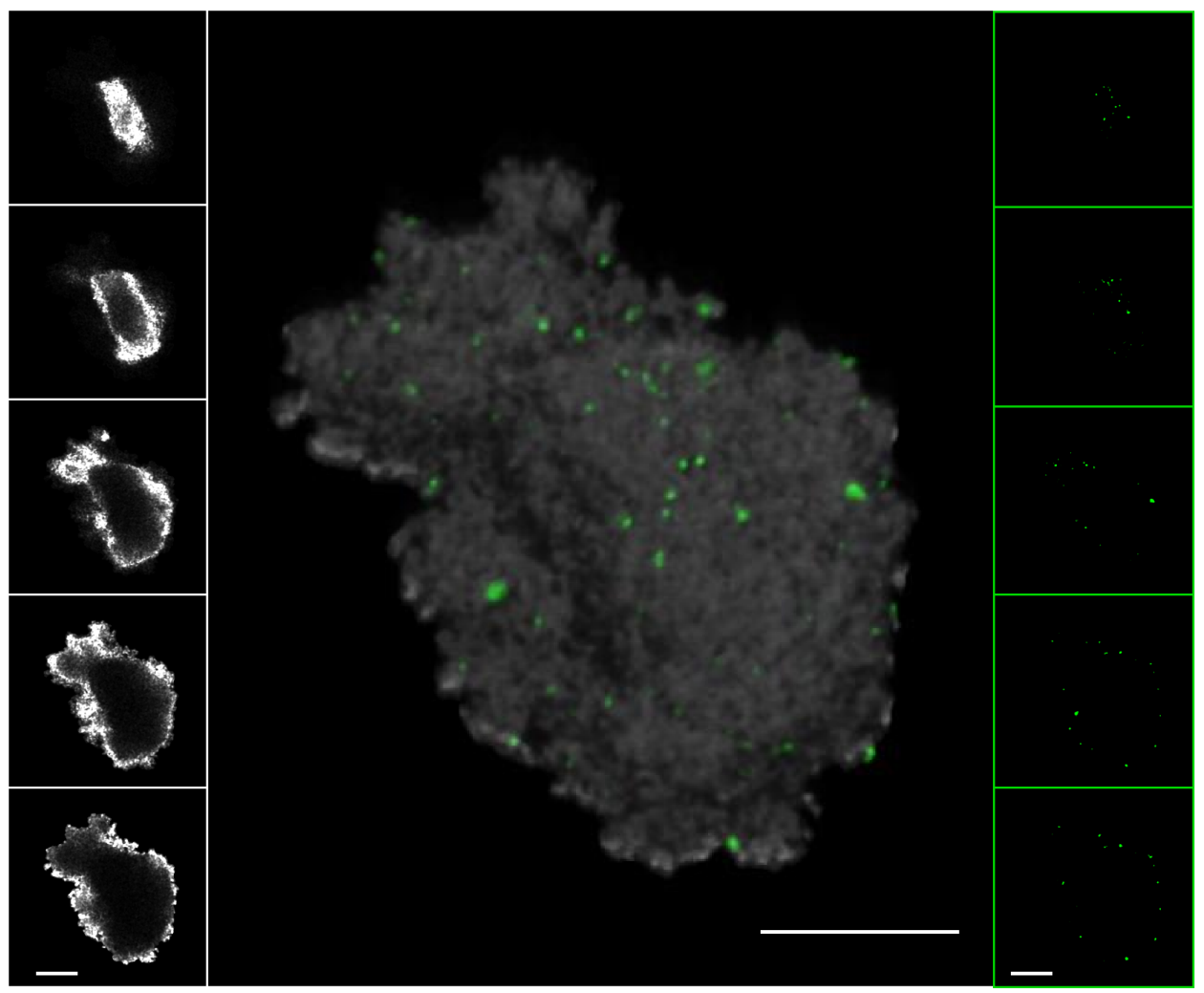

Fig. 5. Example of a black carbon in an experimental study with $0.2 \mu \mathrm{m}$-filtered seawater. Viruses are in green. Several sections of the epifluorescence (right) and the light reflection mode (left) are shown. Scale bars $=10 \mu \mathrm{m}$

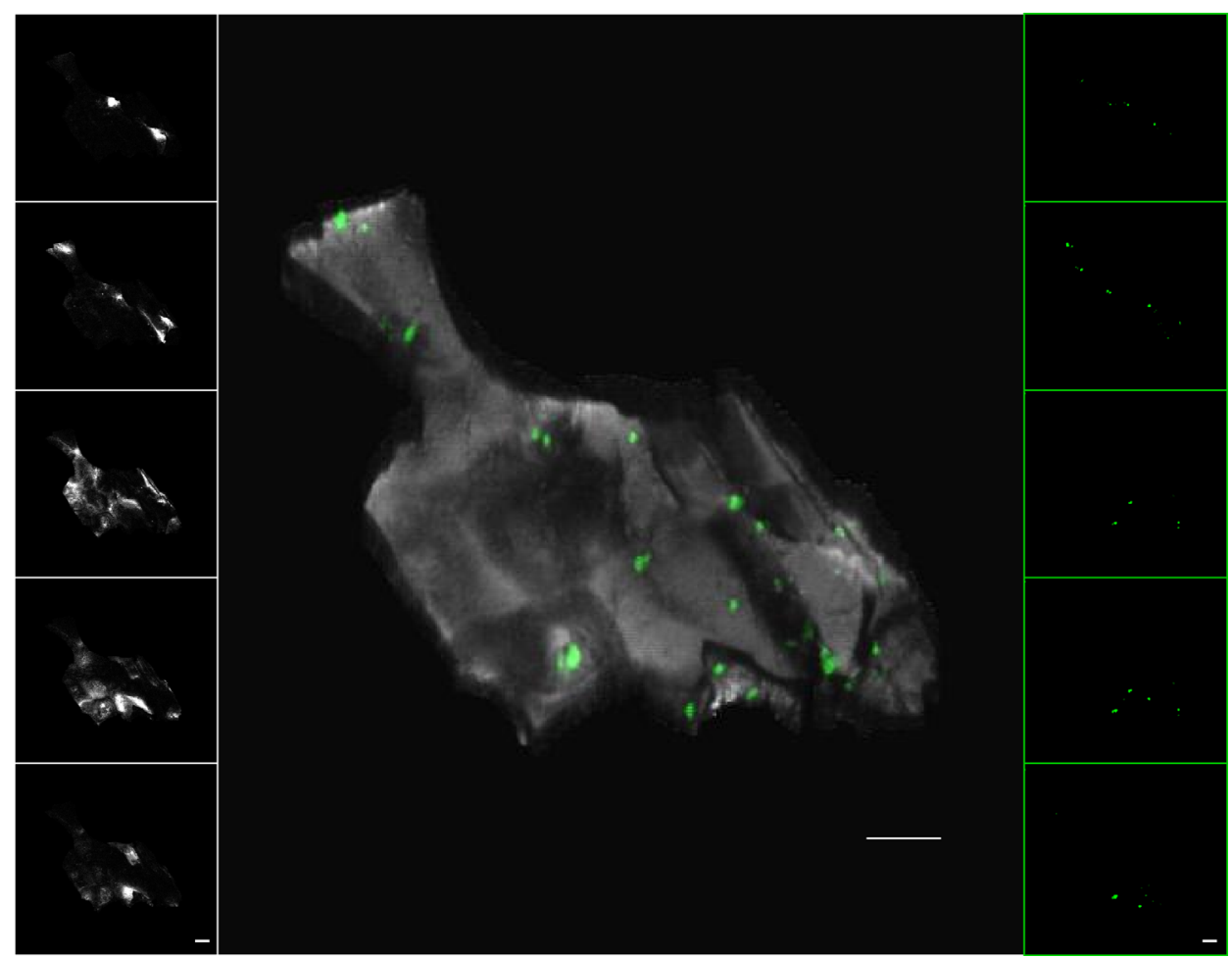

Fig. 6. Example of Saharan dust in an experimental study with seawater. Viruses are in green. Several sections of the epifluorescence (right) and the light reflection mode (left) are shown. Scale bars $=10 \mu \mathrm{m}$ 


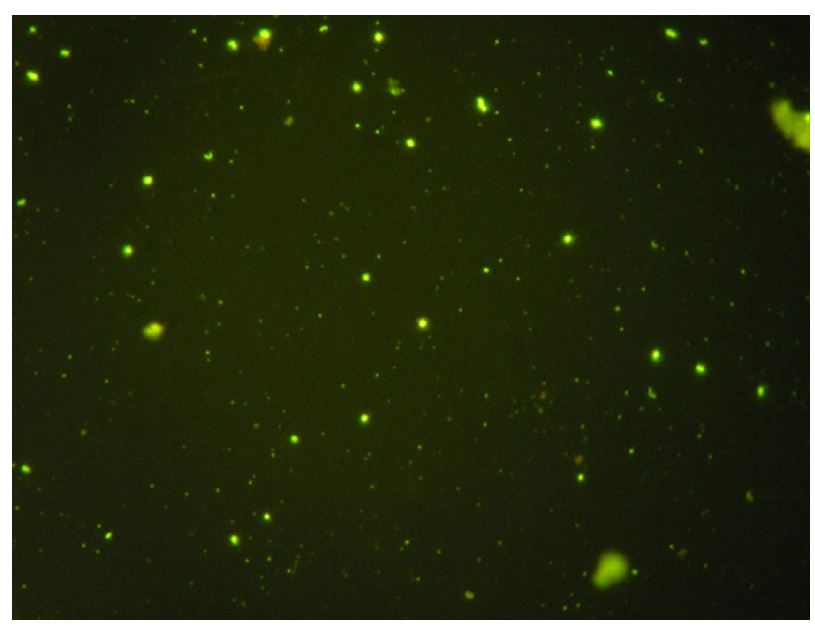

Fig. 7. Viruses and prokaryotes from an experimental marine snow aggregate dissociated with methanol. The larger bright green particles are counted as bacteria and the smaller, more numerous ones are counted as viruses (see Noble \& Fuhrman 1998)

during the $21 \mathrm{~h}$ incubation period. Viral abundance decreased during the initial $5 \mathrm{~h}$ but increased again afterwards. This suggests that the virus reduction approach is applicable in principle. A viral production rate of $9.1 \pm 0.1 \times 10^{5}$ viruses $\mathrm{ml}^{-1} \mathrm{~h}^{-1}$ was calculated (Y. Bettarel et al. unpubl. data). This is comparable to viral production rates in the water column (Winget et al. 2005, Winter et al. 2005); however, more checks, such as on the effects of disruption of aggregates on burst size and prokaryotic growth, have to be made. The virus reduction approach has also been applied to sediments (Danovaro et al. 2008) and there is no reason why it should not work for aggregates. This approach will also likely be applicable to the assessment of the fraction of lytically infected and lysogenic cells (after using an inducing agent) (Weinbauer et al. 2002).

The methanol disruption approach (Lunau et al. 2005) does not only allow for counting viruses on aggregates, but could also facilitate other work on aggregate-associated viruses. For example, TEM detection of visibly infected cells will potentially be possible without thin-sectioning. The so-called whole cell approach has been used to assess the fraction of visibly infected cells and morphotypes and also to estimate burst size (Weinbauer \& Peduzzi 1994). Also, viral diversity work will be possible after disruption of aggregates either using pulsed field gel electrophoresis for genome size distributions (Steward et al. 2000), RAPD-PCR for communities of DNA viruses (Winget \& Wommack 2008), genetic fingerprints for specific viral groups (Cottrell \& Suttle 1995, Fuller et al. 1998, Short \& Suttle 2000) or metagenomics (Breitbart et al. 2002,
Culley et al. 2006). A metagenomic approach combined with a tissue disruption approach was recently applied to study viral diversity associated with corals (Wegley et al. 2007).

\section{OCCURRENCE OF VIRUSES ON PARTICLES}

The first study of viruses on marine snow reported on viruses embedded within the organic aggregates collected from 50 to $400 \mathrm{~m}_{i}$ visibly infected prokaryotic cells in the range of 0.7 to $3.7 \%$ were also detected (Proctor \& Fuhrman 1991). These values are similar to those found in ambient water (Wommack \& Colwell 2000). Using several conversion factors and models (Proctor et al. 1993, Binder 1999, Weinbauer et al. 2002), the highest values of visibly infected cells correspond to mortality estimates, which indicate that viral lysis can be a major factor of prokaryotic mortality on aggregates. Proctor \& Fuhrman (1991) did not find infected cyanobacteria and Chlorella-type cells; however, larger phytoplankton cells, including diatoms with intact frustules, contained viral particles. Fresh salp pellets from plankton nets contained more infected cells than zooplankton pellets from sediments. And all prokaryotic morphotypes except those with intracellular lamellae (potential methylotrophs) contained viruses. Curiously, Proctor \& Fuhrman (1991) is the only study so far on viral infection of prokaryotes on aggregates.

Several studies have assessed viral abundances in aggregates and suspended matter. From these, viral abundance ranged from $10^{5}$ to $10^{11} \mathrm{~cm}^{-3}$ or $\mathrm{ml}^{-1}$ of aggregate (Table 1 ). The first study reported $0.3 \times 10^{7}$ viruses $\mathrm{ml}^{-1}$ in diatom slime (Bratbak et al. 1990). In in situ and experimental studies from the Northern Adriatic Sea, high abundances of 5.6 to $8.7 \times 10^{10}$ viruses $\mathrm{ml}^{-1}$ were found in large marine snow aggregates (Peduzzi \& Weinbauer 1993). These values are similar compared to mature mucilage (up to $1.2-8.7 \times 10^{10}$ viruses $\mathrm{ml}^{-1}$ ) from the same area (Bongiorni et al. 2007). The latter study also showed that viral abundance was lowest on young and intermediate-aged mucilage. The highest viral abundance detected so far (up to $30 \times 10^{10}$ viruses $\mathrm{ml}^{-1}$ ) was found on TEP aggregates in a semi-enclosed bay in the SW lagoon of New Caledonia with a high water residence time (Mari et al. 2007a). In this bay, up to $40 \%$ of the total viral abundance was attached to TEP. In experimental studies simulating a Phaeocystsis bloom, it was estimated that between 10 and $100 \%$ of the viruses could be attached to TEP (Brussaard et al. 2005a). In an experimental study in marine coastal waters with high black carbon (see 'Other particles') additions, up to $50 \%$ of the viruses were attached to black carbon particles, sug- 


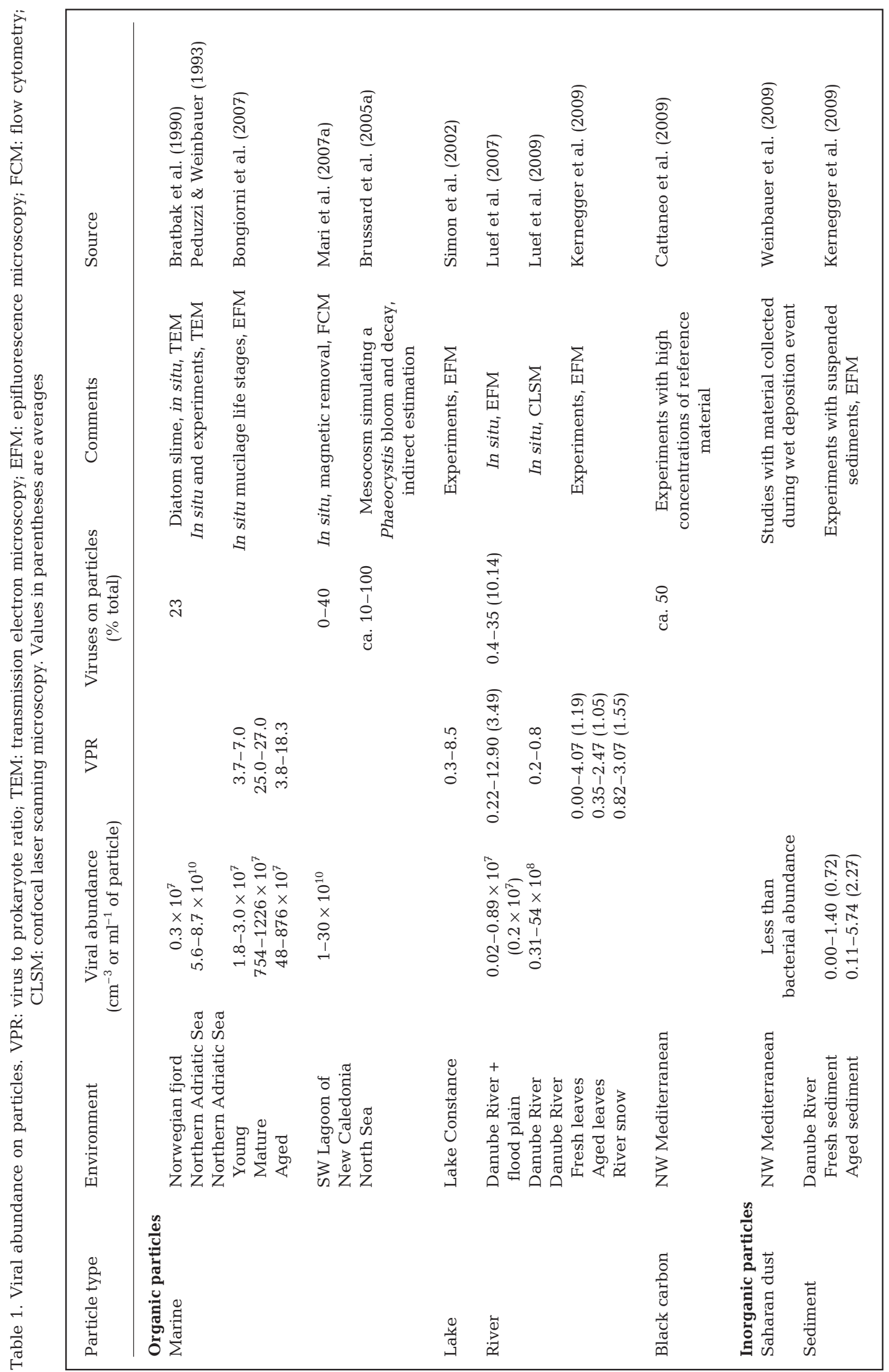


gesting a large potential for this material to adsorb viruses (Cattaneo et al. 2009). Viral abundance on suspended material in a floodplain of the Danube River ranged from 0.02 to $0.89 \times 10^{7} \mathrm{ml}^{-1}$ using EM (Luef et al. 2007). In a follow-up study in the Danube River, viral abundance determined using CLSM was higher and ranged from 0.31 to $54 \times 10^{8}$ viruses $\mathrm{ml}^{-1}$ (Luef et al. 2009). It was estimated that up to $35 \%$ of the viruses could be attached to suspended matter in riverine water. It remains unknown to what extent viruses are truly attached or occur in the pore water of aggregates and suspended matter.

The virus to prokaryote ration (VPR) is sometimes used as a rough indicator for differences in virusprokaryote interactions. The VPR for free-living communities is often 10 or higher. Bongiorni et al. (2007) found VPR ranging from 3.7 to 7.0 in young mucilage, 25.0 to 27.0 in mature mucilage and 3.8 to 18.3 in aged mucilage. In experimental studies performed with water from Lake Constance, VPR of lake snow ranged from 0.3 to 8.5 (Simon et al. 2002) and thus maximum values were as high as in young mucilage. Similar values $(0.22$ to 12.90$)$ were reported for suspended matter in a floodplain of the Danube River (Austria) (Luef et al. 2007). In the Danube River, VPR values of suspended matter were somewhat lower (0.2 to 0.8) (Luef et al. 2009).

There is an apparent tendency for viral abundances and VPR on particles to be higher in marine than freshwater systems. Future studies will have to show whether this observation is a persistent feature or the result of the different types of particles studied or the different methods used. For example, the findings from experimental studies that VPR was low on Saharan dust in marine waters (Weinbauer et al. 2009b) and on suspended sediments in freshwater (Kernegger et al. 2009) supports the idea that the type of particle influences the enumeration of viruses. There is clear evidence that differences in abundances were due to different sizes and qualities of aggregates investigated (see below). However, there are also methodological considerations (see 'Quantification of viral parameters on particles: methods and restrictions') which could have contributed to the large range.

One factor influencing viral abundance is aggregate quality. For example, Luef et al. (2007) found that water age in a sidearm of a river changed the quality of river aggregates and increased prokaryotic growth. Viral abundance increased with the abundance of Alcian Blue and Coomassie Brilliant Blue stained aggregates. This study also suggested higher microbial abundance on aggregates with a higher organic content, as on older aggregates having trapped organic material. Differences between aggregates, such as river snow and fresh and aged leaf litter, have also been demonstrated in experimental studies (Kernegger et al. 2009). Mari et al. (2007a) found that the relationship between the abundance of TEP-attached viruses and the size of TEP was different for 2 ranges of the so-called e-flushing time, a parameter used to estimate water residence time, with higher abundances at higher residence times. They suggest that higher residence time of the water masses results in higher residence time of organic aggregates in the water column. Aggregates remain suspended via a diminution of the stickiness of aggregates, i.e. TEP become less sticky due to prolonged prokaryotic degradation, which in turn reduces the density of aggregates, thus lowering vertical export and enhancing exposure to viruses and to prokaryotic colonization (Mari et al. 2007b). In such a scheme, aggregates occurring in water masses that are poorly renewed may remain suspended in the water column. This longer retention time could result in higher viral infection of colonizing prokaryotes and thus higher viral abundance. The higher viral abundance could also be due to adsorption of free-living viruses due to the longer exposure times. In an experimental study with leaf litter and river snow, it has been shown as well that viral abundance and VPR were higher on aged than on fresh aggregates (Kernegger et al. 2009).

A special type of marine snow is the mucilage in the Northern Adriatic Sea, which can occur in enormous dimensions such as meter-long strings and cloud-like structures or so-called false bottoms. This mucilage can strongly impact coastal ecosystems, for example, by causing anoxia (Herndl 1988, Herndl \& Peduzzi 1988, Herndl 1992, Herndl et al. 1992). Using a variety of chemical and microbiological approaches, 9 different operational types of mucilage formation were grouped into 3 life stages (Bongiorni et al. 2007). During maturation of mucilage, viral and prokaryotic abundance and prokaryotic activity increased on aggregates, whereas these parameters decreased in aging stages. Viral abundance was highest on mature mucilage and intermediate in aged mucilage, whereas VPR was highest in mature mucilage and similar in young and aged mucilage. The results of Bongiorni et al. (2007) suggest that the aggregate quality strongly influences viral abundance.

Luef et al. (2007) found that viral abundance on or in freshwater aggregates increased with aggregate size. A similar relationship was also found for TEP in a coral reef lagoon (Mari et al. 2007a). This is not surprising. However, these studies also showed that viral abundance per aggregate volume or surface area decreased typically with aggregate size. Several types of mechanisms could explain this observation:

(1) Volume-specific bacterial abundances decrease with aggregate size (e.g. Grossart et al. 2003, Luef et 
al. 2007). This could result in lower infection and, hence, lower viral abundance.

(2) The organic matrix could be detrimental for the viruses. For example, enzymatic activity (e.g. aminopeptidases), which is higher on aggregates, could destroy viruses (Simon et al. 2002), which could result in a reduced viral abundance when particles become older.

(3) The existence of prokaryotes on aggregates could reduce viral infection. For example, the depletion of labile organic carbon on older (i.e. larger) organic aggregates could reduce viral infection via reduced host activity. Also, the higher encounter rates might also favour resistance (see 'Viral processes and lifestyles on aggregates') and reduce infection and, thus, viral production on older aggregates.

(4) Finally, since organic aggregates are fractals (Logan \& Wilkinson 1990), viral abundance does not directly scale with the surface area nor the volume of the aggregate (apparent size), rather it scales with its fractal dimension. Thus an increase in aggregate size rather implies a decrease in viral abundance concomitant with an increased porosity of the aggregate, if viruses are attached to the solid fraction of the aggregates.

Apparently, the main factors influencing viral abundance on aggregates are their quality, size and age. It is noteworthy that these parameters are not independent. For example, the quality and size of aggregates can change with age. Other factors such as water residence time are acting indirectly, for example, by keeping aggregates exposed to viruses for a longer time period.

\section{VIRAL PROCESSES AND ORGANIC AGGREGATES}

\section{Operational concept of virus-aggregate interactions}

Many of the potential roles of viral infection in organic matter flux have already been described in the first paper on this topic (Proctor \& Fuhrman 1991). Operationally, 3 different spatial types of viral interactions associated to aggregates can be defined (Fig. 8):

(1) Viral processes in ambient or surrounding water can influence aggregate formation or dissolution. Viruses control or modulate phytoplankton blooms and thus aggregate formations such as algal flocs. In addition, lysis products from algae and prokaryotes may act as biological glues. Finally, viruses might act as nuclei for aggregate formation.

(2) Viral processes such as adsorption or release occur at the interface between the particulate and

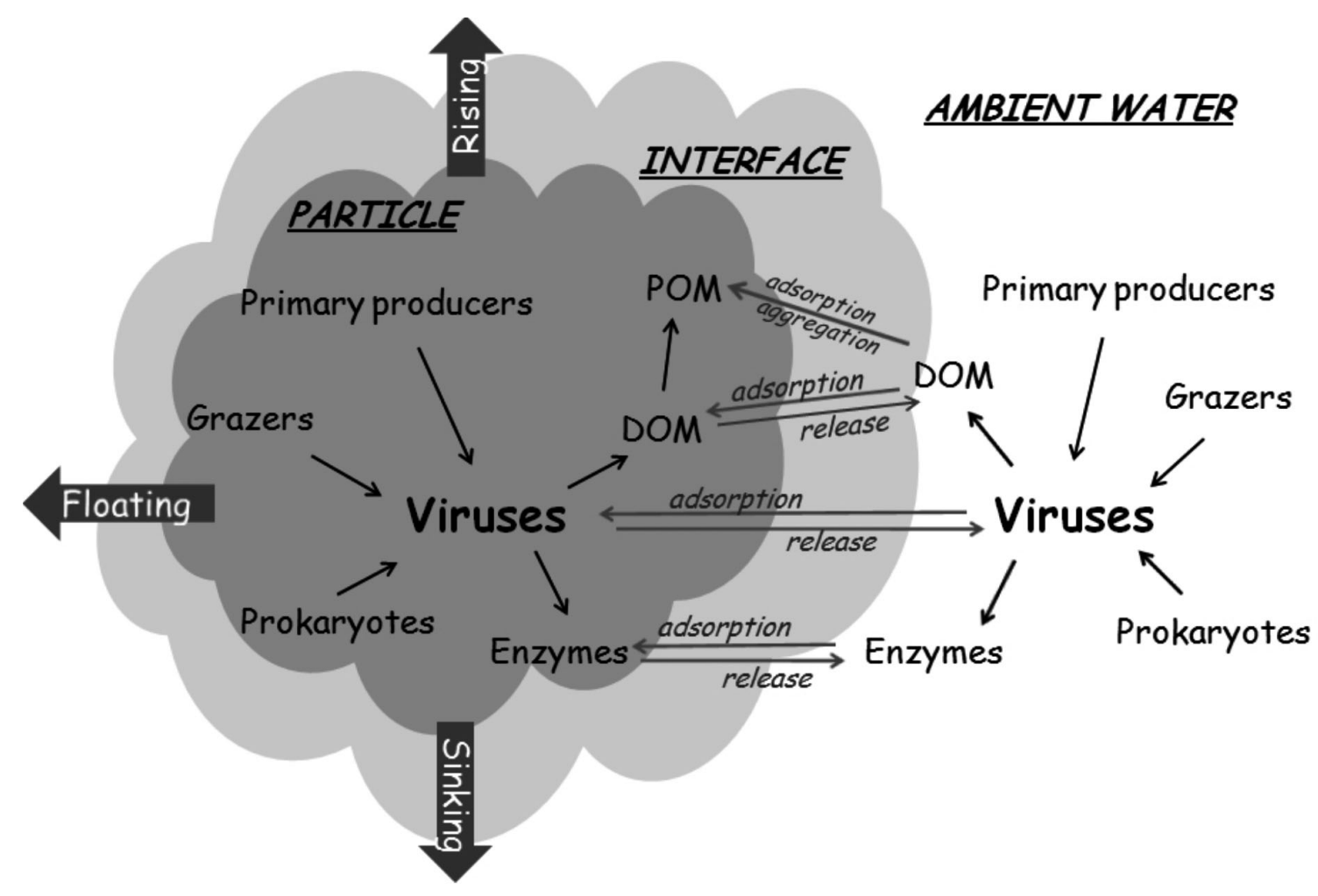

Fig. 8. Model of the potential interactions between virus and aggregates. Arrows point to viruses 
ambient phases. Viruses or viral lysis products adsorb to or are released from aggregates. Adsorption of viruses could be a viral strategy to find hosts populating the aggregates. Aggregates could also be a source, producing viruses and releasing them into the environment. In addition, lysis products could be released and contribute to the increased nutrient concentration and, thus, production around aggregates.

(3) Viral processes inside aggregates will influence the fate of aggregates. Viral lysis products from attached algae and prokaryotes might be sticky and function as biological glue. Viral enzymes such as lysozymes may dissolve aggregates. Enzymes produced by prokaryotes as antiviral defence might also degrade aggregates.

\section{Influence of viral lysis on the quality and quantity of DOM as precursors of aggregates}

DOM is part of the organic matter continuum and can influence aggregate formation. Thus, viral lysis may also influence aggregate formation via changing the DOM field. However, surprisingly few studies have investigated the influence of viral lysis on the composition, concentration and bioavailability of DOM. In a set of experiments, marine microbial communities were enriched ca. 2- to 2.3-fold with concentrates made from the natural virus community (Weinbauer \& Peduzzi 1995). This treatment did not result in an enrichment of dissolved free and combined amino acids (DFAA and DCAA, respectively) and dissolved monomeric and polymeric carbohydrates (DMCHO and DPCHO, respectively) at the start of the experiment. Experiments were performed in light conditions using rolling tanks. Short-term incubations $(<24 \mathrm{~h})$ showed that all measured DOM components were elevated in the viral enrichments together with an increase of prokaryotic abundance. In long-term incubations (24 to $>168 \mathrm{~h}$ ), DFAA and DMCHO were repressed, whereas DCAA and DPCHO as well as total dissolved amino acid and carbohydrate (DTAA and DTCHO, respectively) were stimulated in the viral enrichments compared to controls. Also, prokaryotic abundance was repressed in the presence of viruses, which coincided with a higher fraction of infected cells and higher standing stocks of viruses. The development of chlorophyll a (chl a) concentrations and diatom blooms were also delayed and an analysis of the amino acid composition of DOM suggested viral lysis of diatoms as a source of DOM. Thus the short-term effect was a lubrication of the microbial loop, whereas the long-term effect was an enrichment of total and polymeric DOM.

A change in the DOM field by viral lysis is also suggested by experiments with bacterial isolates. Produc- tion of faintly acridine orange stained submicron colloids, probably by coagulated lysis products, was demonstrated for Vibrio alginolyticus (Shibata et al. 1997). For another Vibrio sp. and a Photobacterium isolate, it was shown that colloid production by viral lysis (e.g. by disruption of cell walls) was more likely than production of empty cells (so called 'ghosts') (Riemann $\&$ Middelboe 2002). In addition, the majority of organic carbon released by viral lysis of Cellulophaga sp. was in the form of DCAA (Middelboe \& Jorgensen 2006).

Overall, viral lysis seems to increase the DOM pool, particularly the polymeric and colloidal components. These components are potential precursors for aggregate formation.

\section{Effect of viruses on the formation and the fate of aggregates}

In the first study investigating the effect of viruses on phytoplankton blooms and marine snow (algal floc) formation, ca. 2.3-fold enrichments of the viral community were used in combination with rolling tanks (Peduzzi \& Weinbauer 1993). Phytoplankton blooms and marine snow are easily produced with rolling tanks for communities from the Adriatic Sea (Herndl et al. 1992). The addition of viruses delayed the phytoplankton bloom (mainly diatoms) and the formation of algal flocs. Maximum chl a concentrations were eventually higher in the virus amendments; however, total accumulated chl a concentrations were similar. Total suspended matter showed a similar time delay compared to the phytoplankton bloom. The main difference was in the size and stability of the algal flocs ( $\geq 1 \mathrm{~mm}$ equivalent spherical diameter): algal flocs in the virus enrichments were larger and more stable than in the controls. These results were confirmed in 2 further experiments (Weinbauer 2004). Such a delay of phytoplankton blooms has also been shown in other studies (Suttle et al. 1990, Suttle 1992). There is also indication that viral infection can delay prokaryotic aggregation or colonization of aggregates (Malits \& Weinbauer 2009).

Viruses have been invoked as a reason for the termination of Phaeocystis and other algal blooms (Bratbak et al. 1993, Nagasaki et al. 1994, Bratbak \& Heldal 2000, Suttle 2000, Tarutani et al. 2000, Evans et al. 2003, Brussaard 2004a). This was also confirmed in a mesocosm study, where the termination of the bloom was associated with a large production of TEP (Brussaard et al. 2005a,b).

Thus, one of the roles viruses play in pelagic waters is to change the temporal patterns of phytoplankton bloom development and termination and, by that, the dynamics of organic aggregates. Although viruses themselves do not affect light scattering (Balch et al. 
1989), the changed size distribution of aggregates due to viral activity could affect light in the surface layer.

\section{Viruses and the biological pump}

There is an ongoing debate with regard to the role of viruses in the biological pump (Brussaard et al. 2008). At least 3 possibilities have been put forward: (1) viruses prime the biological pump by accelerating host export from the euphotic zone (Lawrence \& Suttle 2004), (2) viruses short-circuit the biological pump by releasing nutrients back into the dissolved phase (Poorvin et al. 2004) or (3) viruses drive aggregation and transfer of carbon into the deep sea through the release of sticky colloidal cellular components during viral lysis (Peduzzi \& Weinbauer 1993, Fuhrman 1999).

Lawrence \& Suttle (2004) have developed a conceptual model with 3 scenarios for infected cells of the bloom-forming alga Heterosigma akashiwo and viruses that infect them. This model is based on the strength of the stratification and the water depth and has implications for the biological pump. In scenario 1, when stratification is strong or the pycnocline is deep, cells lyse above the pycnocline and lysis products and viruses remain in the mixed layer. In scenario 2 , when stratification is weak and waters are shallow, infected cells will reach the benthos before lysis; lysis products and viruses are released and remain at the sedimentwater interface. In scenario 3, cells are also not retained by the pycnocline and lysis products and viruses are subject to processes in the deeper water column. The fate of primary production shunted into the DOM and detritus pool will strongly depend on the actual scenario.

Iron fertilization experiments have been performed to test the idea that phytoplankton growth is iron limited and that a relief of this limitation will stimulate phytoplankton production and, subsequently, the flux of sinking aggregates (Boyd et al. 2007). Several mesoscale iron fertilization experiments have been performed so far. Only 2 studies (Strzepek et al. 2005, Weinbauer et al. 2009a) have assessed the effect on the role of viruses and only one compared fertilized and non-fertilized areas (i.e. Weinbauer et al. 2009a). Within the iron-replete patch, viral lysis became by far the dominant factor for the mortality of bacterioplankton (Weinbauer et al. 2009a). Since viral infection also increases prokaryotic respiration in the area where iron fertilization experiments are performed (Middelboe \& Lyck 2002, Bonilla-Findji et al. 2008), and the effect increases with the strength of the viral shunt (Motegi et al. 2009), this probably counteracts the expected increase of the sinking flux of carbon, i.e. short-circuits the biological pump. Nevertheless, the possibility remains that the increased respiration rate and reduced growth efficiency result in an increased remineralization rate of iron (Poorvin et al. 2004, Mioni et al. 2005) and thus sustain primary production and, consequently, carbon export.

As discussed in 'Effect of viruses on the formation and the fate of aggregates', viruses may influence the timing of aggregate formation and the size, quality and stability of aggregates. Depending on the type of aggregates, such as those derived from bacterio-, phyto- or zooplankton, a changed aggregate size distribution by viral lysis may either increase the retention time of POM in the euphotic zone or increase sinking rates. Both general responses will affect the biological pump (Fuhrman 1999). Overall, data suggest that viral infection and lysis can influence the biological pump; however, we do not have a clear picture whether viruses short-circuit or prime the biological pump or drive aggregation and transfer of carbon into the deep-sea. Testing the effect of viruses on the functioning of the biological pump will be an important task for assessing the biogeochemical role of viruses.

\section{Viruses and aggregates in the deep sea}

The deep sea (including surface sediments) is the largest aquatic ecosystem. Nevertheless, very little is known about viruses in the deep sea; knowledge is scarce even for prokaryotes. A metagenomic analysis of deep-sea microorganisms suggested many forms are closely related to those with a surface-attached lifestyle and that microorganisms might be transported with the aggregates into the dark ocean (DeLong et al. 2006). This is supported by findings that the variability of prokaryotic and archaeal parameters in the deep sea, such as DGGE band number and CARD-FISH abundances, showed a large variability, which was linked to the formation of the thermocline and thus probably also to (sinking) phytoplankton blooms (Winter et al. 2009). However, since deep-sea communities differ from surface communities, it is also possible that sinking particles are colonized by specialized deep-sea communities. It has also been speculated that sinking aggregates are a means to transport viruses into the deep sea (Hara et al. 1996, Mari et al. 2007a). For an offshore station outside the Lagoon of New Caledonia, where water depth rapidly drops to $>3000 \mathrm{~m}$ in the New Caledonian Trough, it is known that TEP are negatively buoyant, i.e. they sink (Mari et al. 2007b). Thus, viruses on sinking TEP originating from a tropical lagoon could be an import supply of viruses for the deep sea. Assuming 0.08 fg DNA per virus (Børsheim et al. 1990), attached viruses from the offshore station rep- 
resent a significant amount of (viral) DNA (3 $\mu$ g DNA $\mathrm{l}^{-1}$ ) potentially transported by the biological pump into the deep sea. Thus, sinking TEP might not only transport viruses and phage-host systems to the deep sea and deep-sea sediments, but also provide a substantial supply of viral genetic information.

Virus-aggregate interactions in the deep sea have not been studied so far. It is still not clear how viruses survive in the deep sea and why viral abundances are so high (Ortmann \& Suttle 2005, Magagnini et al. 2007, Parada et al. 2007), although prokaryotic abundance is at least an order of magnitude lower than in surface water (Tanaka \& Rassoulzadegan 2002). One study reports a high percentage of cells with dormant viral genomes (lysogeny) and a low percentage of cells in an irreversible stage of infection (Weinbauer et al. 2003); another suggests that decay rates are much higher than can be supported by the estimated production (Parada et al. 2007); a third, using a virus reduction approach, also indicates low production (C. Griebler \& M. G. Weinbauer unpubl. data); and a metagenomic analysis suggests that lysogenic interactions dominate in deep-sea hydrothermal vents (Williamson et al. 2008). Whether attached viruses play a role in explaining these discrepancies remains unknown.

\section{Hot spots and plumes}

The exchange of solutes between an aggregate and the surrounding water is much higher when the aggregate sinks than when it is drifting (Kiørboe \& Jackson 2001). In a similar way, this exchange should be high in rising aggregates and potentially small in neutrally buoyant aggregates. The differential movement of aggregates compared to ambient water results in a plume of inorganic and organic material originating from the sinking or rising aggregate. It is assumed that chemotactically swimming prokaryotes become concentrated around such hot spots (Blackburn et al. 1998, Grossart et al. 2001, Long \& Azam 2001, Barbara \& Mitchell 2003). This would increase host abundance and, thus, chance of infection. A higher prokaryotic activity at hot spots should also increase infection. An increased infection could interfere with processes producing or dissolving these aggregates.

It has been suggested that leaking cells due to viral infection might attract motile prokaryotes (Riemann \& Middelboe 2002, Riemann \& Grossart 2008). In co-cultures, it has been shown that Cellulophaga sp. cells aggregated around infected cells of Photobacterium sp., whereas healthy Photobacterium sp. cells were not colonized (Middelboe et al. 2003). This indicates that infected or lysing cells can act as sort of miniature hot spots of bioavailable substrate. Infected Cellulophaga sp. were not colonized by Photobacterium sp. This suggests that species-specific phage-prokaryote interactions could be important for aggregate dynamics. It has to be shown whether aggregation around infected cells results in the formation of aggregates or a better utilization and transformation of organic matter by shortening the residence time of lysis products and stimulation of prokaryote-mediated biogeochemical processes.

\section{Viral processes and lifestyles on aggregates}

The typically higher hydrolytic activity of aggregateassociated prokaryotes and the high metabolic activities of grazers on prokaryotes result in inorganic nutrient and DOM concentrations that are much higher in the pore water of aggregates than in the surrounding water (Simon et al. 2002). Prokaryotic growth and size are also typically higher on aggregates. This should increase infection and viral production rates, which often depend on prokaryotic growth rates (Wommack \& Colwell 2000). In addition, the higher viral abundance on aggregates also occurs with higher host abundance. This reduces the distance between viruses and hosts and should result in higher encounter rates (Murray \& Jackson 1992). However, data on encounter rates of viruses with hosts within aggregates are not known, since the restrictions of diffusion on aggregates have not been quantified (Mari et al. 2007a). One can hypothesize that the encounter rates will strongly depend on the porosity of the aggregates, i.e. on the proportion of pore water inside aggregates. Since motile (such as gliding) bacteria are known to populate surfaces, motility inside aggregates could be a main encounter mechanism with viruses (Murray \& Jackson 1992).

To unravel some of the fundamental principles of phage interactions with aggregates, Riemann \& Grossart (2008), used the phage-host system Cellulophaga sp. $-\phi S M$ and agar beads of $15 \mu \mathrm{m}$ diameter. Cellulophaga sp. was grown with and without active phages and with and without beads. In the presence of phages and beads, the growth of free-living and attached prokaryotes was reduced and free-living and attached phage production could be observed. This suggests that attached prokaryotes could be infected and lysed and that the lysis of prokaryotes on agar beads was a source for free-living phages.

The contradiction of elevated phage production on artificial agar particles (beads) (Riemann \& Grossart 2008) and low VPR ratios on some types of aquatic snow (see 'Occurrence of viruses on particles') could be due to another observation in the same study. In a later phase of the experiment, regrowth of attached 
prokaryotes and a new colony morphotype (small round compared to large irregular for the wild-type) could be observed. Isolates of this new morphotype were resistant against infection. Thus it is possible that in early stages of TEP or marine snow formation, phage production is stimulated, whereas in later stages, when resistance dominates and prokaryotic growth is low due to the increasingly refractory nature of the aggregates, phage production decreases. The enhanced viral abundance within aggregates could be a cause for the development of resistance in prokaryotes.

Transduction is the exchange of genetic material between cells by viral activity. Transduction is potentially important for the diversification and diversity of prokaryotes (Weinbauer \& Rassoulzadegan 2004) and is influenced by several factors. For example, transduction seems to occur predominantly when the donor is lytic and the recipient a lysogen, i.e. a cell containing the genome of a dormant phage (Saye et al. 1987, 1990). It has been shown that suspended matter increases transduction frequencies (Ripp \& Miller 1995, Vettori et al. 1999), potentially by bringing hosts and bacteriophages more closely together. Marine, lake and riverine snow could act in a similar way.

It is well known that the community structure of attached prokaryotes often differs from that of free-living prokaryotes (e.g. DeLong et al. 1993). Viral diversity on aggregates has not been investigated yet; however, unpublished data from a study on TEP (Mari et al. 2007a) suggest that the relative abundance of viral FCM groups was different in associated compared to free-living viruses (Table 2). Different FCM groups are likely due to different viral species composition, since FCM stains target nucleic acids and the genome size of a specific viral type is constant. Therefore, this suggests that attached viruses may differ in community composition from free-living viruses. If aggregates are a less favourable environment for viruses (Simon et al. 2002), for example by causing strong viral decay, this could act as a selective force for specific degradationresistant viral types. This also raises the question of whether there are viral types particularly adapted to

Table 2. Viral flow cytometry groups on transparent exopolymer particles (TEP) in Grande Rade Bay, New Caledonia. Data are an unpublished part of a study of viruses on TEP in the SW lagoon of New Caledonia (Mari et al. 2007a). LNA: low nucleic acid; MHNA: middle + high nucleic acid viral group

\begin{tabular}{|lccccc|} 
& \multicolumn{3}{c}{ Midbay- } & & \multicolumn{2}{c|}{ Head of bay- } \\
\cline { 2 - 4 } & \%LNA & \%MHNA & & \%LNA & \%MHNA \\
\hline TEP-associated & 96 & 4 & 87 & 13 \\
Free-living & 78 & 22 & & 79 & 21 \\
\hline
\end{tabular}

the existence on aggregates. A simple explanation would be that different host community compositions select for specific viruses. However, more specific viral strategies could also exist for viruses to either avoid or allow attachment to aggregates depending on whether the hosts have a free-living or attached lifestyle. In addition, viruses could have adaptations to penetrate aggregates such as depolymerazing enzymes as shown for biofilms (see 'Non-pelagic habitats'). If the aggregate matrix is a hostile environment for viruses, either by destroying infectivity or by reducing the access to susceptible host cells, one might also expect lysogeny to become more important (Weinbauer et al. 2003). Viral life strategies associated with aggregates have not been studied so far at the community level.

\section{Influence of virus-aggregate interactions on free- living communities}

Three potential ways in which virus-aggregate interactions can influence free-living communities are discussed here. (1) Viruses could be released from aggregates. This could exert a stronger viral impact of free-living phyto- and bacterioplankton diversity and production. Viral release has been demonstrated in a study with isolates and beads (Riemann \& Grossart 2008). As organic aggregates can disintegrate, such a release is also likely in more natural situations. Release of viruses has been also demonstrated for coral mucus (Weinbauer et al. 2009b). However, as will be argued next section, it is more likely that aggregates typically act as net scavengers of viruses. (2) A principle component analysis of data from an experimental study with water from the Danube River suggests that attached viruses promote the production of free-living prokaryotes (Kernegger et al. 2009). One of the reasons for such an effect could be scavenging of viruses by aggregates and, thus, a reduction of the viral impact. (3) The high viral abundance on aggregates could also be due to strong lysis of attached prokaryotes, which could have resulted in a release of lysis products and stimulated production of free-living prokaryotes. The latter 2 mechanisms are not mutually exclusive. The potential release of lysis products has not been directly studied. In this respect, it is interesting to note that adsorption of viruses to black carbon reference material resulted in an increase of prokaryotic production at a time-scale of $<1$ d (Cattaneo et al. 2009) (see 'Other particles'). This suggests a reduced virus-mediated mortality of free-living prokaryotes rather than a stimulation by release of lysis products for this specific type of particles. Thus, virus-aggregate interactions seem to be beneficial for the growth of the free-living prokaryotes. 


\section{Aggregates: Viral vectors, scavengers or factories?}

It is not known whether aquatic snow can serve as viral reservoir. However, such a function is known for sedimented phytoplankton blooms (Lawrence \& Suttle 2004) and biofilms (Sutherland et al. 2004). In a similar way, specific viruses could remain infective on organic aggregates and finally be released into ambient water by dissolution of aggregates. For inorganic particles, it has been shown that attachment of viruses can reduce decay rates (Kapuscinski \& Michell 1980). Attachment of viruses to aggregates could also be a means of horizontal transport. For example, it has been shown that aggregates are a vector of transport for Vibrio cholerae (Colwell 1996). A similar mechanism could also apply to specific viruses. As the cholera toxin is encoded as phage gene within a prophage in the host genome (Waldor \& Mekalanos 1996), aggregates are also a vector for the prophages carrying the cholera toxin. It is also conceivable that aggregates are a vector for specific viruses resulting in increased infection of organisms such as zooplankton consuming them.

The first study attempting a budget of viral production and decay processes showed that attachment of phages to micro-aggregates was the major loss factor in coastal marine waters in SE Texas (Suttle \& Chen 1992). This study also showed that it was difficult to isolate infectious phages from such aggregates, suggesting inactivation. In addition, it is known that colloids of the high molecular weight DOM (HMW-DOM) fraction can be a major factor in viral decay (Noble \& Fuhrman 1997). Interestingly, these studies suggested that the prokaryotic size fraction was of minor importance for viral decay. The high enzymatic (aminopeptidase) activity on aquatic snow (Simon et al. 2002) could also result in a degradation of viral protein capsids and, thus, decay of aggregates and infectivity. Attachment of viruses and potential inactivation has been suggested for freshwater and marine aggregates (Simon et al. 2002, Brussaard et al. 2005a), which would indicate that aggregates are viral traps.

Thus, one could argue that the lower VPR on organic aggregates (Table 1) is an indication of lower viral impact. However, a relatively low VPR, between $<1$ and $<6$, found in deep-sea sediments was associated with high mortality of prokaryotes (Danovaro et al. 2008). One explanation for this discrepancy could be that, in sediments, contact rates are potentially high due to the high abundances of viruses and their hosts. Thus a significant infection could be possible in the presence of a low VPR due to the reduced distance between viruses and hosts resulting in higher contact rates. The same mechanisms could be operational in organic aggregates: Proctor \& Fuhrman (1991) found a high percentage of visibly infected attached prokary- otes on marine snow aggregates, suggesting significant phage production within aggregates. In addition, a strong release of viruses from aggregates could also result in the low VPR on aggregates. For biofilms, it has been argued that viral enzymatic activity is a way to liberate and release phages from the organic matrix.

Viruses are usually negatively charged in natural environments, as are colloids such as clay (Chattopadhyay \& Puls 2000). These repulsive electrostatic forces are, however, weaker than the attractive van der Waals forces resulting in the adsorption of phages to colloids (Chattopadhyay \& Puls 2000). This could explain the observation that adsorption of viruses to aggregates resulted in a reduced abundance of freeliving viruses (Peduzzi \& Luef 2008). Thus specific aggregates could be net scavengers of viruses. Overall, the data suggest aggregates are viral vectors and scavengers rather than factories releasing viruses into ambient water.

\section{OTHER PARTICLES}

Black carbon is produced by the incomplete combustion of fossil fuels or biomass. It has been recognized as an important carbon pool in marine sediments (Koelmans et al. 2006), whereas for the water column, little information is available due to methodological problems (Masiello 2004). Black carbon originates from chimneys, mufflers and fly ashes from forest fires and constitutes a major component of global warming. Globally, shipping contributes roughly as much particulate matter and BC as road traffic (Eyring et al. 2005). In coastal marine waters, rivers or runoffs after rain are important sources of black carbon (Mitra et al. 2002, Mannino \& Harvey 2004). Black carbon consists of a globular structure of ca. 20 to $30 \mathrm{~nm}$ and is porous, which offers many potential attachment sites for viruses. Indeed, a preliminary experiment with high concentrations of black carbon and $0.2 \mu \mathrm{m}$-filtered, cell-free seawater showed that, within a few hours, more than half the viral community became attached to black carbon (Fig. 9). A CLSM picture of viruses attached to black carbon from diesel from a forklift (standard reference material \#2975, US Department of Commerce, National Institut of Standard and Technology) is shown in Fig. 5. The viral attachment is even faster than for prokaryotes (R. Cattaneo et al. unpubl. data). Additions of black carbon to tanks filled with seawater resulted in increases of prokaryotic abundance and growth (Cattaneo et al. 2009). While it cannot be fully excluded that this is due to use of refractory black carbon by prokaryotes, a strong reduction of viral abundance should also reduce the viral impact on prokaryotes. While there is no indication yet that black 


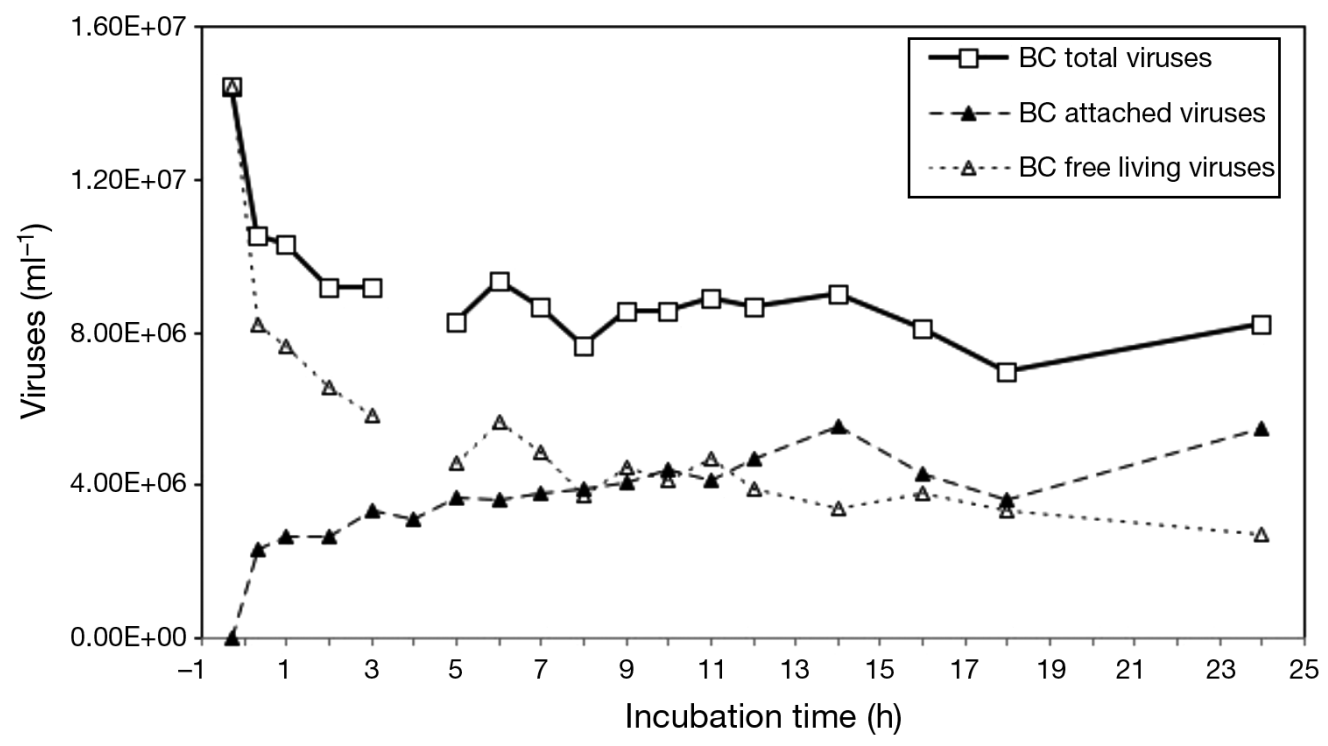

Fig. 9. Time-course of total, attached and free viral abundance in an experiment (R. Cattaneao et al. unpubl. data) with $0.2 \mu \mathrm{m}$-filtered seawater and additions of black carbon (BC) reference material

carbon actually destroys infectivity, the adsorption of viruses could reduce infection rates of the free-living community and thus allow for higher bacterial growth rates. Viral abundance per surface of black carbon decreased with aggregate size, similar to that observed for river and marine snow. This feature had nothing to do with aging aggregates, since black carbon aggregates were added in experiments which lasted only for $24 \mathrm{~h}$ (R. Cattaneo et al. unpubl. data). Also, this could be observed in the absence of cells, i.e. using $0.2 \mu \mathrm{m}$ filtered water. Therefore, this feature should be due to the combination of passive attachment mechanisms and the fractal geometric of black carbon aggregates.

Saharan dust transports significant amounts of nutrients such as phosphorous and iron into the Mediterranean Sea and the Atlantic Ocean. Data also suggest that Saharan dust can be a significant source of bacteria, which can be transported alive across oceans (Gorbushina et al. 2007) and can contain bacteriophages (Prigent et al. 2005, Prestel et al. 2008). These isolated phages belonged to all 3 major double-stranded DNA bacteriophage families: Myoviridae, Siphoviridae and Podoviridae. Whether these phages are able to infect marine or freshwater prokaryotes is not known; however, evidence is accumulating that cross-biome infection can take place (Sano et al. 2004, Bonilla-Findji et al. 2009). Saharan dust particles eventually sink out of the water column. Thus this is a means of removal of viruses and microorganisms from the water column, depending on the attachment rate of organisms onto sinking dust particles. Nevertheless, viruses seem to attach at a lower rate than prokaryotes (Fig. 6), which suggests that viruses could be removed at lower rates than prokaryotes. Saharan dust releases inorganic nutrients such as nitrogen, phosphorous and iron into the environment, which can relieve nutrient limitation and, thus, stimulate phytoplankton growth (Ridame \& Guieu 2002). Also, DOC is released and can stimulate prokaryotic growth (Pulido-Villena et al. 2008). Similar results have been found in an experimental simulation of dust storm event (E. Romero et al. unpubl. data). Such a stimulation of microbial plankton should also stimulate viral production. Indeed, this has been shown in the above-mentioned experiment with Saharan dust collected during a wet deposition event (M. G. Weinbauer unpubl. data).

Inorganic matter, such as calcium carbonate, detrital aluminosilicates and opal, accounts for a large fraction $(>80 \%$ ) of the total mass of sinking particles (Hedges et al. 2001). POM-mineral interactions are crucial because they affect mineral dissolution and organic matter degradation and, thus, sinking fluxes. For example, it has been shown that extracellular proteases can hydrolyze proteins and weaken the structural integrity of diatom frustules (Bidle \& Azam 1999). Additions of viruses resulted in a change of the community composition of prokaryotes attached to organic matter associated to sediments (Hewson et al. 2003). Such a mechanism could also apply to other POMmineral interactions.

\section{NON-PELAGIC HABITATS}

Mucus released from corals can be an important carrier of matter and energy in coral reef systems 
(Wild et al. 2004, Huettel et al. 2006). Thus, in coastal systems, release of mucous substances can be a non-pelagic source of marine snow sensu lato. The coral mucus seems to be depleted with respect to viruses as indicated by the low VPR values (Weinbauer et al. 2009b). Mucus and DOM release can stimulate prokaryotic and viral production with unknown effects on further marine snow formation based on mucus release. POM-rich environments stimulate the growth of microorganisms (Hodges et al. 2005) and, thus, potentially viral production and viral impact.

It may be worthwhile to consider work conducted with biofilms (Sutherland et al. 2004). Monospecific biofilms are often made by exopolymeric substances or capsules. Phages use specific proteins to attach to the polysaccharide capsule of Escherichia coli as well as to degrade it (Nimmich et al. 1991, Scholl et al. 2001). Although not metabolically active or motile, phages can penetrate the biofilms by the use of enzymes (Grimmecke et al. 1994, Ravenscroft et al. 1994, Hänfling et al. 1996), which are located in the tail or capsid, and depolymerize this potential barrier. This depolymerization can result in the collapse of the biofilm. Making a channel through the capsule by enzymatic digestion or reducing the exoplysaccharide viscosity are other ways to access the host cell (Hanlon et al. 2001). It has also been demonstrated that phage infection can change biofilm morphology and that biofilms are a natural reservoir for bacteriophages (Doolittle et al. 1995, Corbin et al. 2001). If a similar mechanism is at work on organic aggregates, infection of cells could not only be due to viruses originating on aggregates but also to viruses penetrating the organic matrix. Finally, depolymerases may play a dual role: phage release from the biofilm and the initial penetration and subsequent infection (Sutherland et al. 2004). To the best of our knowledge, no studies have been performed with natural viral communities on biofilms.

Surfaces of organisms or sediments are other nonpelagic aquatic habitats, where viruses have been investigated. VPR on submerged leaves was 0.2 to 0.3 (Lemke et al. 1997) and ranged from to 0.06 to 0.85 on macrophytes (Juncus effusus) and 0.01 to 0.86 on submerged wood (Farnell-Jackson \& Ward 2003). These values are similar to values from fresh and aged leaf material ( 0 to 4.07) in experimental studies (Kernegger et al. 2009). Freshwater (Filippini et al. 2006, Peduzzi \& Luef 2009) and marine sediments (Hewson \& Fuhrman 2003, Glud \& Middelboe 2004, Danovaro et al. 2008) are comparatively well studied with respect to viruses. The commonly low VPR is a feature sediments share with many other surfaces.

\section{FUTURE RESEARCH AVENUES}

Typically, POM is only considered in sinking fluxes. However, some TEP and marine aggregates are positively buoyant (Azetsu-Scott \& Passow 2004, AzetsuScott \& Niven 2005). Since viral abundance is high in TEP and marine snow, these aggregates may act as an elevator transporting attached viruses to the air-sea interface. It has been previously shown that microorganisms and TEP are enriched in the surface microlayer (top $200 \mu \mathrm{m}$ layer) of the oceans (Agogue et al. 2004, Joux et al. 2006, Wurl \& Holmes 2008). It has also been demonstrated that aerosolization of the surface microlayer (spray) can transfer viruses and TEP (and attached viruses) into the air (Kuznetsova et al. 2005). Thus, the viral elevator could fuel the worldwide spreading of viruses. Flying viruses could impact cloud formation and chemistry. Indeed, it has been shown that virus-sized and virus-like aggregates, prokaryotes and fragments of other microorganisms are not only found in the surface microlayer but also in the atmosphere; these aggregates are likely important as cloud condensation nuclei (Leck \& Bigg 2005). This links virus-aggregate interactions with climate research.

It is well known that the $\mathrm{pCO}_{2}$ level in the ocean has increased in the recent era and, thus, the $\mathrm{pH}$ has decreased; it is assumed that this will have significant biological and climatic consequences (Orr et al. 2005). One study investigated the effect of ocean acidification on TEP properties (Mari 2008). A decrease of $\mathrm{pH}$ within the anticipated level for the end of this century resulted in a reduced TEP stickiness and aggregation and a cessation or even reversal of the downward flux of aggregates. In addition, Mari (2008) found evidence that the size of the TEP pool increases (probably by swelling of TEP), a result also supported by Riebesell et al. (2007). Since longer residence times of organic aggregates in the euphotic zone increased viral abundance within TEP (Mari et al. 2007a), ocean acidification could stimulate the viral shunt within aggregates. Changes in the quality and quantity of TEP should also change bioavailability for prokaryotes and also the viral impact. So far, no studies are available on the effect of ocean acidification on virus-aggregate interactions.

One obvious conclusion from this review is that the number of types of aggregates that have been studied with respect to viral interactions is still small. For many important ecosystems, nothing is known on virusaggregate interactions. For example, river systems are strongly impacted by climate and changes in river morphology, which are likely to trigger alterations in the flow regime and aggregate load or quality. Thus, the potential impact on horizontal transport of aggre- 
gate-associated viruses deserves more and extensive investigation. The deep sea, the largest aquatic ecosystem on Earth, is another example. Other potentially interesting systems are fronts and pycnoclines, where aggregates accumulate. In anoxic systems, interactions between viral communities and aggregates have not been studied at all. Additionally, many virus-related parameters, processes and mechanisms such as viral production and decay, lysogeny, the effect of infection and lysis on microbial community composition or the comparison of viral lysis with bacterivory have been studied for free-living but not yet for aggregateattached communities.

The microbial ecology of organic aggregates in marine and limnetic systems appears to be rather well understood, and the major processes forming and decomposing aggregates have been identified and studied in detail (Simon et al. 2002). Aggregateassociated processes have also been included in food web and biogeochemical models of pelagic systems (Jackson 2001). To incorporate viruses into such models, specific data have to be obtained: (1) quantification of specific pools, such as viral abundance and the frequency of infected and lysogenic cells; (2) quantification of rates of viral production, viral decay, virusmediated host mortality and the release of carbon and other elements due to viral lysis; and (3) processes have to be better constrained, such as the effect of viruses on aggregate formation and dissolution and aggregate buoyancy and quality. Methodological progress or refinement will thus be necessary. Major differences in the way organic aggregates and associated microorganisms are involved in the dynamics of nutrients, DOM and POM exist between pelagic marine and limnetic systems with rather weak hydrodynamic forcing, and shallow and turbid marine, estuarine, riverine and lacustrine systems with strong and highly variable hydrodynamic forcing (Simon et al. 2002). To determine whether or not viral impacts also differ between these 2 general types of systems will be a challenge for years to come. Our understanding of species and the functional diversity of aquatic viruses and microorganisms has made a leap forward by methodological progress. This allows researchers to link studies on diversity with those on ecosystem function and biogeochemical cycles, and is also applicable to the study of virus-aggregate interactions. The application of molecular tools will help assess the biodiversity of attached viral communities and the potential for specific adaptations of viral types for existence on aggregates. Such information can then be scaled up to assess the role of virus-aggregate interactions in microbial biodiversity, ecosystem functioning and biogeochemical cycles.
Acknowledgements. This research was financed by the projects ANR-AQUAPHAGE (no. ANR 07 BDIV 015-06; coordinator: M.G.W) and ANR-MAORY (no. ANR 07 BLAN 016; coordinator: X.M.) from the French Science Ministry and by grants from the Austrian Science Foundation (grant nos. P14721 and P17798 to P.P.). The help of T. Neu from the Umweltforschungszentrum (Magdeburg, Germany) and C. Rouvière from the Observatoire d'Océanographie de Villefranche (Villefranche, France) with confocal laser scanning microscopy is appreciated. The very valuable comments of 2 anonymous reviewers helped to improve the paper; the help of J. Dolan for checking the English is appreciated.

\section{LITERATURE CITED}

Agogue H, Casamayor E, Joux F, Obernosterer I and others (2004) Comparison of samplers for the biological characterization of the sea surface microlayer. Limnol Oceanogr Methods

Alldredge AL, Passow U, Logan BE (1993) The abundance and significance of a class of large, transparent organic particles in the ocean. Deep-Sea Res I 40:1131-1140

Allen MJ, Wilson WH (2008) Aquatic virus diversity accessed through omic techniques: a route map to function. Curr Opin Microbiol 11:226-232

Azam F (1998) Microbial control of oceanic carbon flux: the plot thickens. Science 280:694-696

Azam F, Long RA (2001) Sea snow microcosms. Nature 414: $495-498$

Azam F, Malfatti F (2007) Microbial structuring of marine ecosystems. Nat Rev Microbiol 5:782-791

Azam F, Fenchel T, Field JG, Gray JS, Meyer-Reil LA, Thingstad F (1983) The ecological role of water-column microbes in the sea. Mar Ecol Prog Ser 10:257-263

Azetsu-Scott K, Niven SEH (2005) The role of transparent exopolymeric particles (TEP) in the transport of ${ }^{234} \mathrm{Th}$ in coastal water during a spring bloom. Cont Shelf Res 25:1133-1141

Azetsu-Scott K, Passow U (2004) Ascending marine particles: significance of transparent exopolymeric partciles (TEP) in the upper ocean. Limnol Oceanogr 49:741-748

Balch WM, Eppley RW, Abbott MR, Reid FMH (1989) Bias in satellite-derived pigment measurements due to coccolithophores and dinoflagellates. J Plankton Res 11:575-581

Barbara GM, Mitchell JG (2003) Bacterial tracking of motile algae. FEMS Microbiol Ecol 44:79-87

$>$ Bergh Ø, Børsheim KY, Bratbak G, Heldal M (1989) High abundance of viruses found in aquatic environments. Nature 340:467-468

Biddanda BA (1985) Microbial synthesis of macroparticulate matter. Mar Ecol Prog Ser 20:241-251

Bidle KD, Azam F (1999) Accelerated dissolution of diatom silica by marine bacterial assemblages. Nature 397:508-512

Binder B (1999) Reconsidering the relationship between virally induced bacterial mortality and frequency of infected cells. Aquat Microb Ecol 18:207-215

Blackburn N, Fenchel T, Mitchell J (1998) Microscale nutrient patchiness in planktonic habitats shown by chemotactic bacteria. Science 282:2254-2256

- Bongiorni L, Armeni M, Corinaldesi C, Dell'Anno A, Pusceddu A, Danovaro R (2007) Viruses, prokaryotes and biochemical composition of organic matter in different types of mucilage aggregates. Aquat Microb Ecol 49: 15-23

Bonilla-Findji O, Malits A, Lefèvre D, Rochelle-Newall E, Lemée R, Weinbauer M, Gattuso JP (2008) Viral effects on bacterial respiration, production and growth efficiency: 
consistent trends in the Southern Ocean and the Mediterranean Sea. Deep-Sea Res II 55:790-800

Bonilla-Findji O, Rochelle-Newall E, Weinbauer MG, Pizay MD, Kerros ME, Gattuso JP (2009) Effect of seawater-freshwater cross-transplantations on viral dynamics and bacterial diversity and production. Aquat Microb Ecol 54:1-11

Børsheim KY, Bratbak G, Heldal M (1990) Enumeration and biomass estimation of planktonic bacteria and viruses by transmission electron microscopy. Appl Environ Microbiol 56:352-356

Boyd PW, Jickells T, Law CS, Blain S and others (2007) Mesoscale iron enrichment experiments 1993-2005: synthesis and future directions. Science 315:612-617

Bratbak G, Heldal M (2000) Significance of algal viruses and ecology of Phaeocystis host-virus interactions. In: Bell C, Brylinsky M, Johnson-Green P (eds) Microbial biosystems. Atlantic Canada Society for Microbial Ecology, Halifax, p 571-575

Bratbak G, Heldal M, Norland S, Thingstad TF (1990) Viruses as partners in spring bloom microbial trophodynamics. Appl Environ Microbiol 56:1400-1405

Bratbak G, Heldal M, Thingstad TF, Riemann B, Haslund OH (1992) Incorporation of viruses into the budget of microbial C-transfer. A first approach. Mar Ecol Prog Ser 83:273-280

Bratbak G, Egge JK, Heldal M (1993) Viral mortality of the marine alga Emiliania huxleyi (Haptophycaea) and termination of algal blooms. Mar Ecol Prog Ser 93:39-48

Breitbart M, Salamon P, Andresen B, Mahaffy JM and others (2002) Genomic analysis of uncultured marine viral communities. Proc Natl Acad Sci USA 99:14250-14255

Brussaard CP (2004a) Viral control of phytoplankton populations-a review. J Eukaryot Microbiol 51:125-138

Brussaard CPD (2004b) Optimization of procedures for counting viruses by flow cytometry. Appl Environ Microbiol 70:1506-1513

Brussaard C, Kuipers B, Veldhuis M (2005a) A mesocosm study of Phaeocystis globosa (Prymnesiophyceae) population dynamics: I. Regulatory role of viruses in bloom control. Harmful Algae 4:859-874

Brussaard C, Mari X, van Bleijswijk JDL, Veldhuis M (2005b) A mesocosm study of Phaeocystis globosa (Prymnesiophyceae) population dynamics: II. Significance for the microbial community. Harmful Algae 4:875-893

Brussaard CP, Wilhelm SW, Thingstad F, Weinbauer MG and others (2008) Global-scale processes with a nanoscale drive: the role of marine viruses. ISME J 2:575-578

Cattaneo R, Rouvière C, Malits A, Sintes E and others (2009) Black carbon: a new player structuring microbial processes in marine coastal waters. ASLO Aquatic Sciences Meeting, 25-30 Jan 2009, Nice, France (Abstract)

Chattopadhyay S, Puls RW (2000) Forces dictating colloidal interactions between viruses and soil. Chemosphere 41: 1279-1286

Chin WC, Orellana MV, Verdugo P (1998) Spontaneous assembly of marine dissolved organic matter into polymer gels. Nature 392:568-572

> Colwell RR (1996) Global climate and infectious disease: the cholera paradigm. Science 274:2025-2031

> Corbin BD, McLean RJ, Aron GM (2001) Bacteriophage T4 multiplication in a glucose-limited Escherichia coli biofilm. Can J Microbiol 47:680-684

> Cottrell MT, Suttle CA (1995) Genetic diversity of algal viruses which lyse the photosynthetic picoflagellate Micromonas pusilla (Prasinophyceae). Appl Environ Microbiol 61:3088-3091

> Culley AI, Lang AS, Suttle CA (2006) Metagenomic analysis of coastal RNA virus communities. Science 312:1795-1798
Danovaro R, Dell'Anno A, Magagnini M, Noble R, Tamburini C, Weinbauer MG (2008) Major viral impact on the functioning of benthic deep-sea ecosystems. Nature 454:1084-1087

DeLong EF, Franks DG, Alldregde AL (1993) Phylogenetic diversity of aggregate-attached vs. free-living marine bacterial assemblages. Limnol Oceanogr 38:924-934

DeLong EF, Preston CM, Mincer T, Rich V and others (2006) Community genomics among stratified microbial assemblages in the ocean's interior. Science 311:496-503

Doolittle MM, Cooney JJ, Caldwell DE (1995) Lytic infection of Escherichia coli biofilms by bacteriophage T4. Can J Microbiol 41:12-18

- Evans C, Archer S, Jacquet S, Wilson W (2003) Direct estimates of the contribution of viral lysis and microzooplankton grazing to the decline of a Micromonas spp. population. Aquat Microb Ecol 30:207-219

Eyring V, Köhler HW, van Ardenne J, Lauer A (2005) Emissions from international shipping: 1 . The last 50 years. J Geophys Res 110, doi:10.1029/2004JD005619

> Farnell-Jackson EA, Ward AK (2003) Seasonal patterns of viruses, bacteria and dissolved organic carbon in a riverine wetland. Freshw Biol 48:841-851

Farrah SR (ed) (1987) Ecology of phage in freshwater environments. John Wiley \& Sons, New York

Filippini M, Buesing N, Bettarel Y, Sime-Ngando T, Gessner MO (2006) Infection paradox: high abundance but low impact of freshwater benthic viruses. Appl Environ Microbiol 72:4893-4898

- Fuhrman JA (1999) Marine viruses and their biogeochemical and ecological effects. Nature 399:541-548

> Fuller NJ, Wilson WH, Joint IR, Mann NH (1998) Occurrence of a sequence in marine cyanophages similar to that of T4 g20 and its application to PCR-based detection and quantification techniques. Appl Environ Microbiol 64: 2051-2060

Glud RN, Middelboe M (2004) Virus and bacteria dynamics of a coastal sediment: implication for benthic carbon cycling. Limnol Oceanogr 49:2073-2081

Gorbushina AA, Kort R, Schulte A, Lazarus D and others (2007) Life in Darwin's dust: intercontinental transport and survival of microbes in the nineteenth century. Environ Microbiol 9:2911-2922

Grimmecke HD, Knirel YA, Shashkov AS, Kiesel B, Lauk W, Voges M (1994) Structure of the capsular polysaccharide and the O-side-chain of the lipopolysaccharide from Acetobacter methanolicus $\mathrm{MB} 70$, and of oligosaccharides resulting from their degradation by the bacteriophage Acm6. Carbohydr Res 253:277-282

Grossart HP, Simon M (1993) Limnetic macroscopic organic aggregates (lake snow): abundance, characteristics, and bacterial dynamics in Lake Constance. Limnol Oceanogr 38:532-546

Grossart HP, Riemann L, Azam F (2001) Bacterial motility in the sea and its ecological implications. Aquat Microb Ecol 25:247-258

Grossart HP, Hietanen S, Ploug H (2003) Microbial dynamics on diatom aggregates in Øresund, Denmark. Mar Ecol Prog Ser 249:69-78

Hänfling P, Shashkov AS, Jann B, Jann K (1996) Analysis of the enzymatic cleavage ( $B$ elimination) of the capsular K5 polysaccharide of Escherichia coli by the K5-specific coliphage: a reexamination. J Bacteriol 178:4747-4750

> Hanlon GW, Denyer SP, Olliff CJ, Ibrahim LJ (2001) Reduction in exopolysaccharide viscosity as an aid to bacteriophage penetration through Pseudomonas aeruginosa biofilms. Appl Environ Microbiol 67:2746-2753 
Hara S, Koike I, Terauchi K, Kamiya H, Tanoue E (1996) Abundance of viruses in deep oceanic waters. Mar Ecol Prog Ser 145:269-277

Hedges JI (2002) Why dissolved organics matter. In: Hansell DA, Carlson CA (eds) Biogeochemsitry of marine dissolved organic matter. Academic Press, San Diego, CA, p 1-33

> Hedges JI, Baldock JA, Gelinas Y, Lee C, Peterson M, Wakeham SG (2001) Evidence for non-selective preservation of organic matter in sinking marine particles. Nature 409: 801-804

Herndl GJ (1988) Ecology of amorphous aggregations (marine snow) in the Northern Adriatic Sea. II. Microbial density and activity in marine snow and its implication to overall pelagic processes. Mar Ecol Prog Ser 48:265-275

Herndl GJ (1992) Marine snow in the northern Adriatic Sea: possible causes and consequences for a shallow ecosystem. Mar Microb Food Webs 6:149-172

Herndl GJ, Peduzzi P (1988) The ecology of amorphous aggregations (marine snow) in the Northern Adriatic Sea: I. General considerations. PSZNI: Mar Ecol 9:79-90

Herndl GJ, Karner M, Peduzzi P (1992) Floating mucilage in the northern Adriatic Sea: the potential of a microbial ecological approach to solve the 'mystery'. Sci Total Environ 126(Suppl):525-538

Hewson I, Fuhrman JA (2003) Viriobenthos production and virioplankton sorptive scavenging by suspended sediment particles in coastal and pelagic waters. Microb Ecol 46: 337-347

> Hewson I, Vargo GA, Fuhrman JA (2003) Bacterial diversity in shallow oligotrophic marine benthos and overlying waters: effects of virus infection, containment, and nutrient enrichment. Microb Ecol 46:322-336

> Hodges LR, Bano N, Hollibaugh JT, Yager PL (2005) Illustrating the importance of particulate organic matter to pelagic microbial abundance and community structure - an Arctic case study. Aquat Microb Ecol 40:217-227

Huettel M, Wild C, Gonelli S (2006) Mucus trap in coral reefs: formation and temporal evolution of particle aggregates caused by coral mucus. Mar Ecol Prog Ser 307:69-84

Jackson GA (2001) 25: effect of coagulation on a model planktonic food web. Deep-Sea Res I 48:95-123

Joux F, Agogué H, Obernosterer I, Dupuy C, Reinthaler T, Herndl GJ, Lebaron P (2006) Microbial community structure in the sea surface microlayer at two contrasting coastal sites in the northwestern Mediterranean Sea. Aquat Microb Ecol 42:91-104

Kapuscinski RB, Michell R (1980) Processes controlling virus inactivation in coastal waters. Water Res 14:363-371

Karner M, Herndl GJ (1992) Extracellular enzymatic activity and secondary production in free-living and marinesnow-associated bacteria. Mar Biol 113:341-347

Kernegger L, Zweimüller I, Peduzzi P (2009) Effects of suspended matter quality and virus abundance on microbial parameters: experimental evidence from a large European river. Aquat Microb Ecol 57:161-173

Kiørboe T, Jackson G (2001) Marine snow, organic solute plumes, and optimal chemosensory behavior of bacteria. Limnol Oceanogr 43:1309-1318

Koelmans AA, Jonker MT, Cornelissen G, Bucheli TD, Van Noort PC, Gustafsson O (2006) Black carbon: the reverse of its dark side. Chemosphere 63:365-377

Koike I, Hara S, Terauchi K, Kogure K (1990) Role of submicrometre particles in the ocean. Nature 345:242-244

- Kuznetsova M, Lee C, Aller J (2005) Characterization of the proteinaceous matter in marine aerosols. Mar Chem 96: 359-377

Lawrence J, Suttle C (2004) Effect of viral infection on sinking rates of Heterosigma akashiwo and its implication for bloom termination. Aquat Microb Ecol 37:1-7
Leck C, Bigg EK (2005) Biogenic particles in the surface microlayer and overlaying atmosphere in the central Arctic Ocean during summer. Tellus Ser B Chem Phys Meterol 57:305-316

Lemke M, Wickstrom C, Leff L (1997) Preliminary study on the distribution of viruses and bacteria in lotic environments. Arch Hydrobiol 141:67-74

Leppard G, Heissenberger A, Herndl G (1996) Ultrastructure of marine snow. I. Transmission electron microscopy methodology. Mar Ecol Prog Ser 135:289-298

> Lisle JT, Priscu JC (2004) The occurrence of lysogenic bacteria and microbial aggregates in the lakes of the McMurdo Dry Valleys, Antarctica. Microb Ecol 47:427-439

Logan BE, Wilkinson DB (1990) Fractal geometry of marine snow and other biological aggregates. Limnol Oceanogr 35:130-136

Long RA, Azam F (1996) Abundant protein-containing particles in the sea. Aquat Microb Ecol 10:213-221

Long R, Azam F (2001) Microscale patchiness of bacterioplankton assemblage richness in seawater. Aquat Microb Ecol 26:103-113

Luef B, Aspetsberger F, Hein T, Huber F, Peduzzi P (2007) Impact of hydrology on free-living and particle-associated microorganisms in a river floodplain system (Danube, Austria). Freshw Biol 52:1043-1057

Luef B, Neu T, Peduzzi P (2009a) Imaging and quantifying virus fluorescence signals on aquatic aggregates: a new method and its implication for aquatic microbial ecology. FEMS Micobiol Ecol 68:372-380

Luef B, Neu TR, Zweimüller I, Peduzzi P (2009b) Structure and compostion of aggregates in two large European rivers, based on confocal laser scanning microscopy and image and statistical analysis. Appl Environ Microbiol 18:5952-5962

Lunau M, Lemke A, Walther K, Martens-Habbena W, Simon M (2005) An improved method for counting bacteria from sediments and turbid environments by epifluorescence microscopy. Environ Microbiol 7:961-968

> Magagnini M, Corinaldesi C, Monticelli LS, DeDomenico E, Danovaro R (2007) Viral abundance and distribution in mesopelgic and bathypelagic waters of the Mediterranean Sea. Deep-Sea Res I 54:1209-1220

> Malits A, Weinbauer MG (2009) Effect of turbulence and viruses on aggregate formation and prokaryotic cell size, production and diversity. Aquat Microb Ecol 54: $243-254$

Mannino A, Harvey H (2004) Black carbon in estuarine and coastal ocean dissolved organic matter. Limnol Oceanogr 49:735-740

Mari X (2008) Does ocean acidification induce an upward flux of marine particles? Biogeosciences 5:1023-1031

> Mari X, Kerros ME, Weinbauer MG (2007a) Virus attachment to transparent exopolymeric particles along trophic gradients in the southwest lagoon of New Caledonia. Appl Environ Microbiol 73:5245-5252

Mari X, Rochelle-Newall E, Torréton JP, Pringault O, Jouon A, Migon C (2007b) Water residence time: a regulatory factor of the DOM to POM transfer efficiency. Limnol Oceanogr 52:808-819

Masiello CA (2004) New directions in black carbon organic geochemistry. Mar Chem 92:201-213

Middelboe M, Jorgensen N (2006) Viral lysis of bacteria: an important source of dissolved amino acids and cell wall compounds. J Mar Biol Assoc UK 86:605-612

Middelboe M, Lyck PG (2002) Regeneration of dissolved organic matter by viral lysis in marine microbial communities. Aquat Microb Ecol 27:187-194 
Middelboe M, Riemann L, Steward C, Hannsen W, Nybroe O (2003) Virus-induced transfer of organic carbon released between marine bacteria in a model community. Aquat Microb Ecol 33:1-10

- Mioni CE, Poorvin L, Wilhelm SW (2005) Virus and siderophore-mediated transfer of available Fe between heterotrophic bacteria: characterization using an Fe-specific bioreporter. Aquat Microb Ecol 41:233-245

Mitra S, Bianchi TS, McKee BA, Sutula M (2002) Black carbon from the Mississippi River: quantities, sources, and potential implications for the global carbon cycle. Environ Sci Technol 36:2296-2302

Moebus K (ed) (1987) Ecology of marine bacteriophages. John Wiley \& Sons, New York

Mostajir B, Dolan J, Rassoulzadegan F (1995) A simple method for the quantification of a class of labile marine pico- and nano-sized detritus: DAPI Yellow Particles (DYP). Aquat Microb Ecol 9:259-266

Motegi C, Nagata T, Miki T, Weinbauer MG, Legendre L, Rassoulzadegan F (2009) Viral control of bacterial growth efficiency in marine pelagic environments. Limnol Oceanogr 54:1901-1910

> Murray AG, Jackson GA (1992) Viral dynamics: a model of the effects of size, shape, motion and abundance of singlecelled planktonic organisms and other particles. Mar Ecol Prog Ser 89:103-116

Nagasaki K, Ando M, Itakura S, Imai I, Ishida Y (1994) Viral mortality in the final stage of Heterosigma akashiwo (Raphidophycea) red tide. J Plankton Res 16:1595-1599

Nagata T (2008) Organic matter-bacteria interactions in seawater. In: Kirchman DL (ed) Microbial ecology of the oceans, 2nd edn. John Wiley \& Sons, New York, p 207-241

Nagata T, Kirchman D (1997) Roles of submicron particles and colloids in microbial food webs and biogeochemical cycles within marine environments. Adv Microb Ecol 15:81-103

Neu T (2000) In situ cell and glycoconjugate distribution in river snow studied by confocal laser scanning microscopy. Aquat Microb Ecol 21:85-95

Nimmich W, Schmidt G, Krallmann-Wenzel U (1991) Two different Escherichia coli capsular polysaccharide depolymerases each associated with one of the coliphage phi K5 and phi K20. FEMS Microbiol Lett 66:137-141

Noble RT, Fuhrman JA (1997) Virus decay and its causes in coastal waters. Appl Environ Microbiol 63:77-83

Noble R, Fuhrman JA (1998) Use of SYBR Green I for rapid epifluorescence counts of marine viruses and bacteria. Aquat Microb Ecol 14:113-118

> Orr JC, Fabry VJ, Aumont O, Bopp L and others (2005) Anthropogenic ocean acidification over the twenty-first century and its impact on calcifying organisms. Nature 437:681-686

Ortmann AC, Suttle CA (2005) High abundances of viruses in a deep-sea hydrothermal vent system indicates viral mediated microbial mortality. Deep-Sea Res I 52: 1515-1527

Parada V, Sintes E, van Aken HM, Weinbauer MG, Herndl GJ (2007) Viral abundance, decay, and diversity in the mesoand bathypelagic waters of the North Atlantic. Appl Environ Microbiol 73:4429-4438

Peduzzi P, Luef B (2008) Viruses, bacteria and suspended particles in a backwater and main channel site of the Danube (Austria). Aquat Sci 70:186-194

Peduzzi P, Luef B (2009) Viruses. In: Likens G (ed) Encyclopedia of inland waters. Elsevier, Oxford, p 279-294

Peduzzi P, Weinbauer MG (1993) Effect of concentrating the virus-rich 2-200-nm size fraction of seawater on the formation of algal flocs (marine snow). Limnol Oceanogr 38:1562-1565
Pomeroy LR (1974) The ocean's food web, a changing paradigm. Bioscience 24:499-504

Poorvin L, Rinta-Kanto J, Hutchins DA, Wilhelm S (2004) Viral release of iron and its bioavailability to marine plankton. Limnol Oceanogr 49:1734-1741

Prestel E, Salamitou S, DuBow MS (2008) An examination of the bacteriophages and bacteria of the Namib Desert. J Microbiol 46:364-372

Prigent M, Leroy M, Confalonieri F, Dutertre M, DuBow MS (2005) A diversity of bacteriophage forms and genomes can be isolated from the surface sands of the Sahara Desert. Extremophiles 9:289-296

Proctor LM, Fuhrman JA (1990) Viral mortality of marine bacteria and cyanobacteria. Nature 343:60-62

Proctor LM, Fuhrman JA (1991) Roles of viral infection in organic particle flux. Mar Ecol Prog Ser 69:133-142

Proctor LM, Okubo A, Fuhrman JA (1993) Calibrating estimates of phage-induced mortality in marine bacteria: ultrastructural studies of marine bacteriophage development from one-step growth experiments. Microb Ecol 25:161-182

> Pulido-Villena E, Wagener T, Guieu C (2008) Bacterial response to dust pulses in the western Mediterranean: implications for carbon cycling in the oligotrophic ocean. Global Biogeochem Cycles 22:GB1020

Ravenscroft N, Parolis LAS, Parolis H (1994) Bacteriophage degradation of Klebsiella K30 capsular polysaccharide. An NMR investigation of the 3,4-pyruvated galactose-containing repeating oligosaccharide. Carbohydr Res 254: 333-340

Ridame C, Guieu C (2002) Saharan input of phosphate to the oligotrophic water of the open Western Mediterranean Sea. Limnol Oceanogr 47:856-869

Riebesell U, Schulz KG, Bellerby RG, Botros M and others (2007) Enhanced biological carbon consumption in a high $\mathrm{CO}_{2}$ ocean. Nature 450:545-548

> Riemann L, Grossart HP (2008) Elevated lytic phage production as a consequence of particle colonization by a marine Flavobacterium (Cellulophaga sp.). Microb Ecol 56: 505-512

Riemann L, Middelboe M (2002) Viral lysis of marine bacterioplankton: implications for organic matter cycling and bacterial clonal composition. Ophelia 56:57-68

Ripp S, Miller RV (1995) Effects of suspended particles on the frequency of transduction among Pseudomonas aerugonosa in a freshwater environment. Appl Environ Microbiol 61:1214-1219

Samo TJ, Malfatti F, Azam F (2008) A new class of transparent organic particles in seawater visualized by a novel fluorescence approach. Aquat Microb Ecol 53:307-321

Sano E, Carlson S, Wegley L, Rohwer F (2004) Movement of viruses between biomes. Appl Environ Microbiol 70: 5842-5846

Saye DJ, Ogunseitan O, Sayler GS, Miller RV (1987) Potential for transduction of plasmids in a natural freshater environment: effect of plasmid donor concentration and natural microbial community on transduction in Pseudomnonas aeruginosa. Appl Environ Microbiol 53:9897-9995

Saye DJ, Ogunseitan OA, Sayler GS, Miller RV (1990) Transduction of linked chromosomal genes between Pseudomonas aeruginosa strains during incubation in situ in a freshwater habitat. Appl Environ Microbiol 56: 140-145

Scholl D, Rogers S, Adhya S, Merril CR (2001) Bacteriophage K1-5 encodes two different tail fiber proteins, allowing it to infect and replicate on both K1 and K5 strains of Escherichia coli. J Virol 75:2509-2515 
Shibata A, Kogure K, Koike I, Ohwada K (1997) Formation of submicron colloidal particles from marine bacteria by viral infection. Mar Ecol Prog Ser 155:303-307

Short SM, Suttle CA (2000) Denaturing gradient gel electrophoresis resolves virus sequences amplified with degenerate primers. Biotechniques 28:20-26

Silver MW, Shanks AL, Trent JD (1978) Marine snow: microplankton habitat and source of small-scale patchiness in pelagic populations. Science 201:371-373

Simon M, Grossart HP, Schweitzer B, Ploug H (2002) Microbial ecology of organic aggregates in aquatic ecosystems. Aquat Microb Ecol 28:175-211

Smith DC, Simon M, Alldredge AL, Azam F (1992) Intense hydrolytic enzyme activity on marine snow aggregates and implication for rapid particle dissolution. Nature 359:139-142

Steward G, Montiel J, Azam F (2000) Genome size distributions indicate variability and similarity among marine viral assemblages from diverse environments. Limnol Oceanogr 45:1697-1706

Strzepek RF, Maldonado MT, Higgins JL, Hall J, Safi K, Wilhelm SW, Boyd PW (2005) Spinning the 'ferrous wheel': the importance of the microbial community in an iron budget during the FeCycle experiment. Global Biogeochem Cycles 19:GB4S26

Sutherland IW, Hughes KA, Skillman LC, Tait K (2004) The interaction of phage and biofilms. FEMS Microbiol Lett 232:1-6

Suttle CA (1992) Inhibition of photosynthesis in phytoplankton by the submicron size fraction concentrated from seawater. Mar Ecol Prog Ser 87:105-112

Suttle C (2000) Ecological, evolutionary, and geochemical consequences of viral infection of cyanobacteria and eukaryotic algae. In: Hurst C (ed) Viral ecology. Academic Press, San Diego, CA, p 247-296

Suttle CA (2005) Viruses in the sea. Nature 437:356-361

Suttle CA, Chen F (1992) Mechanisms and rates of decay of marine viruses in seawater. Appl Environ Microbiol 58: 3721-3729

Suttle CA, Chan AM, Cottrell MT (1990) Infection of phytoplankton by viruses and reduction of primary productivity. Nature 347:467-469

Tanaka T, Rassoulzadegan F (2002) Full-depth profile (0-2000 $\mathrm{m})$ of bacteria, heterotrophic nanoflagellates and ciliates in the NW Mediterranean Sea: vertical partitioning of microbial trophic structures. Deep-Sea Res II 49:2093-2107

Tarutani K, Nagasaki K, Yamaguchi M (2000) Viral impacts on total abundance and clonal composition of the harmful bloom-forming phytoplankton Heterosigma akashiwo. Appl Environ Microbiol 66:4916-4920

Verdugo P, Alldredge AL, Azam F, Kirchman DL, Passow U, Santschi PH (2004) The oceanic gel phase: a bridge in the DOM-POM continuum. Mar Chem 92:67-85

Vettori C, Stotzky G, Yoder M, Gallori E (1999) Interaction between bacteriophage PBS1 and clay minerals and transduction of Bacillus subtilis by clay-phage complexes. Environ Microbiol 1:347-355

Waldor MK, Mekalanos JJ (1996) Lysogenic conversion by a filamentous phage encoding cholera toxin. Science 272: 1910-1914

Wegley L, Edwards R, Rodriguez-Brito B, Liu H, Rohwer F (2007) Metagenomic analysis of the microbial community associated with the coral Porites astreoides. Environ Microbiol 9:2707-2719

> Weinbauer MG (2004) Ecology of prokaryotic viruses. FEMS Microbiol Rev 28:127-181

Weinbauer MG, Peduzzi P (1994) Frequency, size and distribution of bacteriophages in different marine bacterial morphotypes. Mar Ecol Prog Ser 108:11-20
Weinbauer MG, Peduzzi P (1995) Effect of virus-rich high molecular weight concentrates of seawater on the dynamics of dissolved amino acids and carbohydrates. Mar Ecol Prog Ser 127:245-253

Weinbauer MG, Rassoulzadegan F (2004) Are viruses driving microbial diversification and diversity? Environ Microbiol 6:1-11

Weinbauer M, Winter C, Höfle M (2002) Reconsidering transmission electron microscopy based estimates of viral infection of bacterioplankton using conversion factors derived from natural communities. Aquat Microb Ecol 27:103-110

Weinbauer M, Brettar I, Höfle M (2003) Lysogeny and virusinduced mortality of bacterioplankton in surface, deep, and anoxic waters. Limnol Oceanogr 48:1457-1465

Weinbauer MG, Arrieta JM, Griebler C, Herndl GJ (2009a) Enhanced viral production and infection of bacterioplankton during an iron-induced phytoplankton bloom in the Southern Ocean. Limnol Oceanogr 54:774-784

Weinbauer MG, Maier C, Cattaneo R, Mari X, Gasol JM, Peduzzi P, Rassoulzadegan F (2009b) Interactions of viruses and bacteria with organic and inorganic particles. ASLO Aquatic Sciences Meeting, 25-30 Jan 2009, Nice, France (Abstract)

Weinbauer MG, Rowe JM, Wilhelm SW (in press) MAVE: Determining rates of virus production in aquatic systems by the virus reduction approach. In: Suttle C, Wilhelm SW, Weinbauer MG (eds) Manual of aquatic viral ecology. Limnol Oceanogr Methods, p 1-8, www.aslo.org/books/

> Wells ML, Goldberg ED (1991) Occurence of small colloids in sea water. Nature 353:342-344

Wen K, Ortmann AC, Suttle CA (2004) Accurate estimation of viral abundance by epifluorescence microscopy. Appl Environ Microbiol 70:3862-3867

Wild C, Huettel M, Klueter A, Kremb SG, Rasheed MY, Jorgensen BB (2004) Coral mucus functions as an energy carrier and particle trap in the reef ecosystem. Nature 428:66-70

Wilhelm SW, Suttle CA (1999) Viruses and nutrient cycles in the Sea. Bioscience 49:781-788

Wilhelm SW, Brigden SM, Suttle CA (2002) A dilution technique for the direct measurement of viral production: a comparison in stratified and tidally mixed coastal waters. Microb Ecol 43:168-173

Williamson SJ, Cary SC, Williamson KE, Helton RR, Bench SR, Winget D, Wommack KE (2008) Lysogenic virus-host interactions predominate at deep-sea diffuse-flow hydrothermal vents. ISME J 2:1112-1121

> Winget DM, Wommack KE (2008) Randomly amplified polymorphic DNA (RAPD)-PCR as a tool for assessment of marine viral richness. Appl Environ Microbiol 74: 2612-2618

> Winget D, Williamson K, Helton R, Wommack K (2005) Tangential flow dilafiltration: an improved technique for estimation of virioplankton production. Aquat Microb Ecol 41:221-232

Winter C, Smit A, Szoeke-Dénes T, Herndl GJ, Weinbauer MG (2005) Modelling viral impact on bacterioplankton in the North Sea using artificial neural networks. Environ Microbiol 7:881-893

Winter C, Kerros ME, Weinbauer MG (2009) Seasonal changes of bacterial and archaeal communities in the dark ocean: evidence from the Mediterranean Sea. Limnol Oceanogr 54:160-170

- Wommack KE, Colwell RR (2000) Virioplankton: viruses in aquatic ecosystems. Microbiol Mol Biol Rev 64:69-114

> Wurl O, Holmes M (2008) The gelatinous nature of the seasurface microlayer. Mar Chem 110:89-97 